\title{
Participatory GIS for growth management in the Cheat Lake planning district of Monongalia County, West Virginia
}

Timothy L. Hawthorne

West Virginia University

Follow this and additional works at: https://researchrepository.wvu.edu/etd

\section{Recommended Citation}

Hawthorne, Timothy L., "Participatory GIS for growth management in the Cheat Lake planning district of Monongalia County, West Virginia" (2005). Graduate Theses, Dissertations, and Problem Reports. 702. https://researchrepository.wvu.edu/etd/702

This Thesis is protected by copyright and/or related rights. It has been brought to you by the The Research Repository @ WVU with permission from the rights-holder(s). You are free to use this Thesis in any way that is permitted by the copyright and related rights legislation that applies to your use. For other uses you must obtain permission from the rights-holder(s) directly, unless additional rights are indicated by a Creative Commons license in the record and/ or on the work itself. This Thesis has been accepted for inclusion in WVU Graduate Theses, Dissertations, and Problem Reports collection by an authorized administrator of The Research Repository @ WVU. For more information, please contact researchrepository@mail.wvu.edu. 
Participatory GIS for Growth Management in the Cheat Lake Planning District of Monongalia County, West Virginia

Timothy L. Hawthorne

Thesis submitted to the

Eberly College of Arts and Sciences at West Virginia University in partial fulfillment of the requirements

for the degree of

\author{
Master of Arts \\ in \\ Geography
}

Daniel Weiner, Ph.D., Chair

Gregory Elmes, Ph.D.

Brent McCusker, Ph.D.

Department of Geology and Geography

Morgantown, West Virginia

2005

Keywords: Participatory GIS, Land Use Planning, Local Knowledge, West Virginia

Copyright 2005 Timothy L. Hawthorne 


\begin{abstract}
Participatory GIS for Growth Management in the Cheat Lake Planning District of Monongalia County, West Virginia
\end{abstract}

\author{
Timothy L. Hawthorne
}

Participatory Geographic Information Systems (PGIS) can be an effective methodology for collecting public input in local land use planning and smart growth management. PGIS-based approaches provide residents with an opportunity to discuss and map their priority land use issues and to identify land use hotspots in a way that is not typically possible in a general public meeting. This thesis research explores how community qualitative information about land use can be incorporated into a PGIS for the Cheat Lake Planning District of Monongalia County, West Virginia. The research presented in this thesis demonstrates how qualitative information strengthens land use planning and improves communication about smart growth management options at the local level. Multimedia information, such as community narratives, mental maps, and geo-referenced photographs are collected using qualitative research methods and combined with existing geo-spatial information in order to shape future political discussions about land use planning in the case study area. 


\section{Acknowledgements}

I would like to thank several people and agencies for their support with this thesis research. First and foremost, I would like to thank my thesis advisor, Dr. Daniel Weiner, for sharing his knowledge and research ideas with me over the last two years. His comments and ideas were particularly useful and encouraging throughout the writing process. I would also like to thank my other committee members, Dr. Gregory Elmes and Dr. Brent McCusker, for their helpful comments throughout the research process.

Two agencies provided funding for this research. This thesis research was made possible by the generous financial support of the West Virginia University Regional Research Institute. Major financial support for this research was also provided by "The College and University Affiliations Program for a Partnership Between West Virginia University, the University of Pretoria and Catholic University of Mozambique" from the U.S. Information Agency.

I would also like to thank my family and friends for their emotional support over the years. To my mom, dad, and Matt: your love and support throughout my entire life have made me the person I am today. To John Krygier, thanks for all your encouraging words and emails (even after OWU) and for helping me get started in geography. To Josh, our witty banter in the LUCC lab and our wickedly competitive 8 am racquetball games were nice reprieves from the trials and tribulations of graduate student life.

Last, but certainly not least, I would like to thank Alicia for her love and support over the past five years. Alicia, you have helped me grow in so many ways over the last five years. You have been there for me when I am up and more importantly you keep me standing tall when I am about to fall. The drives along I-79 and the turnpike have been long and expensive, but worth it. Here's to our next chapter... 


\section{Participatory GIS for Growth Management in the Cheat Lake Planning District of Monongalia County, West Virginia}

\section{Timothy L. Hawthorne}

Abstract $\quad$ ii

Acknowledgements $\quad$ iii

Table of Contents $\quad$ iv

Figures $\quad \mathrm{v}$

Tables $\quad$ vi

$\begin{array}{ll}\text { Chapter 1: Introduction } & 1\end{array}$

Chapter 2: Conceptual Framework and Literature Review

2.1 GIS and Society Conceptual Framework 5

2.2 Participatory GIS $\quad 8$

2.3 Land Use Planning 11

2.4 Merging Participatory GIS and Land Use Planning 14

$\begin{array}{ll}2.5 \text { Conclusion } & 16\end{array}$

Chapter 3: Case Study and Methodology

3.1 Case Study Area: Cheat Lake Planning District, West Virginia 18

3.2 Methodology 21

$\begin{array}{ll}3.3 \text { Conclusion } & 30\end{array}$

Chapter 4: Results and Discussion

4.1 PGIS for Increased Participation in Local Land Use Planning 31

4.2 Impact of Local Political Context on the CLPD PGIS 32

4.3 Merging Academic \& Community Questions through PGIS 33

4.4 Empowering Marginalized Communities through PGIS 34

4.5 Identifying and Mapping Critical Community Themes with PGIS 35

$\begin{array}{ll}4.6 \text { Conclusion } & 47\end{array}$

$\begin{array}{ll}\text { Chapter 5: Summary and Conclusions } & 48\end{array}$

$\begin{array}{ll}\text { Literature Cited } & 54\end{array}$ 


\section{List of Figures}

Figure 1.1: Location of Case Study Area 2

Figure 3.1: 2004 Cheat Lake Planning District Land Use Classifications 19

Figure 4.1: 2004 Cheat Lake Planning District Subdivisions 36

Figure 4.2: Composite Map of Community Defined Flooding Hotspots 39 and FEMA Flood Hazards

Figure 4.3: Community Defined Flooding Hotspot 40

Figure 4.4: Community Defined Transportation Concerns 42

Figure 4.5: Composite Map of Preservation Opportunities 44

Figure 4.6: Composite Map of Trails and Walkways 45

Figure 4.7: Potential Preservation Opportunity 46 


\section{List of Tables}

Table 3.1: Cheat Lake Planning District Key Informants 26

Table 3.2: Cheat Lake Planning District Focus Groups 27

Table 3.3: Participant Defined Themes for Line and Polygon Layers in PGIS 29 


\section{Chapter 1: Introduction}

Participatory Geographic Information Systems (PGIS) integrate participatory methodologies with geo-spatial technologies in order to better represent the characteristics of a particular place. Over the last decade, researchers within a GIS and Society conceptual framework have attempted to integrate local knowledge held by members of a community into such systems.

Participatory GIS are tailored to answer specific geographic questions at the local level and their modes of implementation vary considerably across space, ranging from field-based, qualitative approaches to more complex web-based applications. With this broad range of techniques, PGIS are becoming an effective methodology for incorporating community local knowledge into complex spatial decision-making processes in locations where the local planning infrastructure is in place and access to geo-spatial technologies already exist (Craig et al, 2002).

In this thesis, a PGIS case study involving the Cheat Lake Planning District (CLPD) of Monongalia County, West Virginia is presented (Figure 1.1 below). The Cheat Lake Planning District is located in a high growth corridor east of Morgantown and suffers from rapid growth without the needed planning infrastructure, institutions, and regulations. As a result, there is "dumb growth" taking place in the area and there is also a growing desire by members of the local community for more effective land use planning (Hawthorne et al, forthcoming). This marks an important change in local social attitudes because resistance to planning has been the dominant discourse until recently. The Cheat Lake Planning District thus offers an interesting case study highlighting one Participatory GIS methodological approach for encouraging residential participation and for integrating community local knowledge into land use planning. 


\section{Monongalia County, West Virginia Planning Districts}

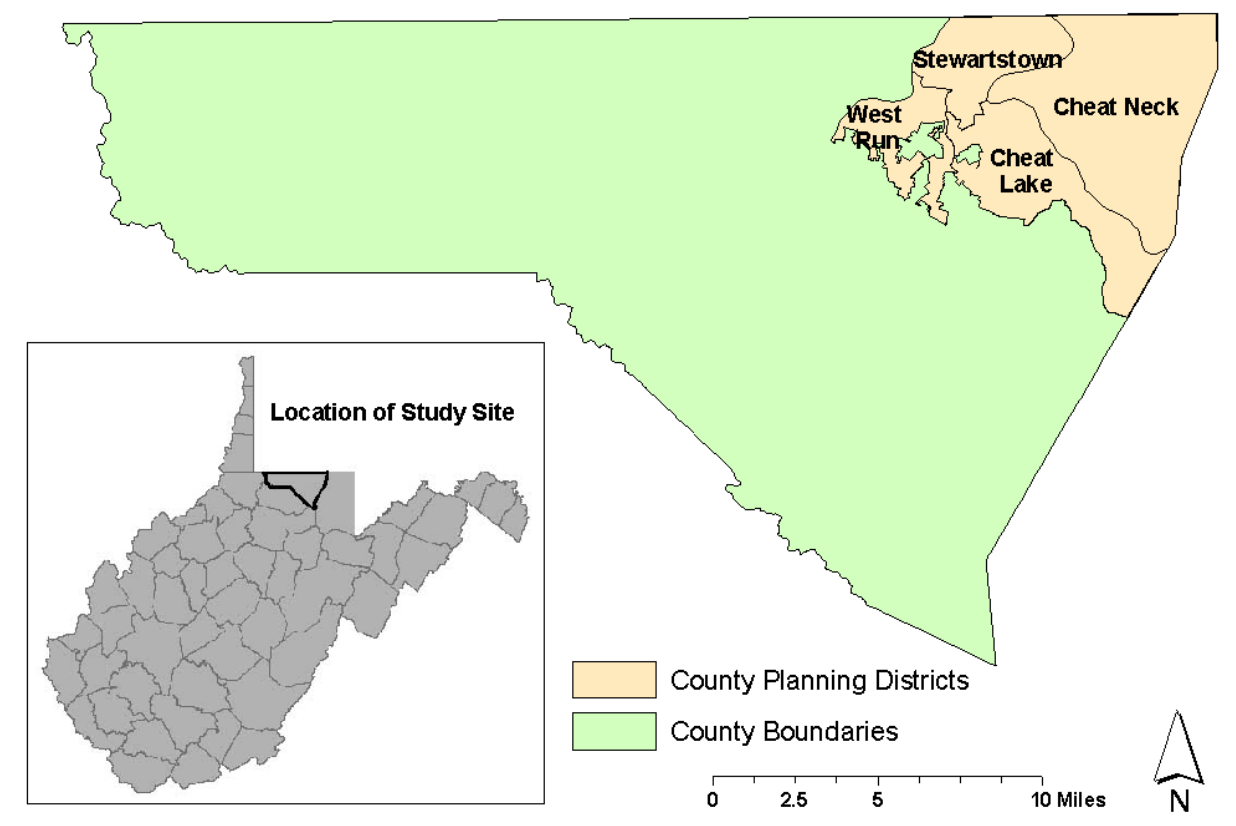

Figure 1.1: Location of Case Study Area

Historically, the Cheat Lake area has had low residential densities, some agricultural land uses, large forested areas, and rural landscapes. Over the last decade, the City of Morgantown, located just west of the Cheat Lake area, has experienced rapid economic growth and increased need for new housing and commercial development. Recent growth in the city and county has led to a significant conversion of rural land in the planning district to higher density and inadequately connected residential areas and some small-scale commercial developments. Increases in population, development, and traffic congestion have placed significant pressures on Cheat Lake's existing road network, public school facilities, fire protection services, and natural storm water drainage. Additionally, some residents and homeowner associations have voiced strong concerns that continued unregulated growth might threaten remaining areas in the community where rural characteristics, natural areas, and portions of undeveloped land exist. In response to the community's desire for growth management strategies, the Monongalia County Commission created the Cheat Lake Planning District as provided by West Virginia’s planning enabling law. 
The Cheat Lake Planning District Advisory Committee (CLPDAC) of the Monongalia County Planning Commission was created to work in conjunction with the county planning office to develop a future land use vision for the planning district and to propose zoning regulations for consideration by the County Commission. The research for this thesis reports on the partnership between the Monongalia County Planning Office, the West Virginia University (WVU) Department of Geology and Geography, and the WVU Regional Research Institute, which resulted in a PGIS methodology for land use planning research in the Cheat Lake Planning District of Monongalia County, West Virginia.

This research links land use planning with geo-spatial technologies through a PGIS methodology and allows the county planning office and the planning district advisory committee to learn more about community land use concerns in ways that would not have been possible in a typical county land use planning process. In many land use planning processes, large public meetings are held where participants are given a limited opportunity to voice their concerns. In these meetings, there is often less of an opportunity for the public to interact with geo-spatial technologies for visualizing their concerns. It is important to understand that while the collaborative PGIS approach used in this research brings more participants into local land use planning, the methodology cannot be generalized to the entire Cheat Lake Planning District population.

In the chapters that follow, the motivations for a PGIS methodology in the case study area and the major research findings are discussed. After an introduction to the project, chapter two of this thesis places the research within a broader GIS and Society conceptual framework and highlights the main objectives of Participatory Geographic Information Systems. The importance of and limitations to participation in land use planning are also discussed in chapter two. Four case studies which merge PGIS methodologies with land use planning at the local level are also summarized in chapter two.

The Cheat Lake Planning District of Monongalia County, West Virginia, which serves as the case study site for this research is explored in chapter three. The PGIS methodology with multiple participatory methods, which focus largely on qualitative data collection techniques including focus group discussions, in-depth key informant 
interviews and participatory mapping is discussed in chapter three. The chapter ends with a discussion about how data collected from these participatory methods are integrated into a Participatory Geographic Information System for the case study area.

Five major findings of the research are discussed in chapter four. Figures documenting results of the PGIS process are also discussed in chapter four to show what a PGIS methodology can add to local land use planning.

A summary and conclusion of the thesis research and a discussion of the possible implications of continued collaborative planning efforts are included in chapter five. How the findings of this research will affect future discussions about land use planning and smart growth in the planning district are also outlined in chapter five. 


\section{Chapter 2: Conceptual Framework and Literature Review}

\section{Chapter 2 Summary}

The conceptual framework and literature which guide the thesis research are presented in this chapter. Sections one and two place the research within a broader GIS and Society conceptual framework and review the main themes of Participatory Geographic Information Systems. The importance of and limitations to participation in land use planning are discussed in section three. Four case studies, which merge Participatory GIS methodologies with land use planning, are summarized in section four. The chapter ends with conclusions learned from reviewing the PGIS and land use planning literatures, which serve as the basis for this thesis research.

\subsection{GIS and Society Conceptual Framework}

In the early 1990s as the use of Geographic Information Systems expanded, many researchers felt that more critical analyses of the technology were needed. As a result, GIS researchers and social theorists forged a theoretical critique of the use of GIS and its impacts on society. Researchers began to ask questions that aimed to hold the technology accountable socially, economically, politically, and ethically (Chrisman, 1987; Crampton, 1995; Harris et al, 1995; Pickles, 1995; Sheppard, 1993). Within the discipline of geography, these critiques of GIS technology formed a broadly defined GIS and Society conceptual framework. This GIS and Society conceptual framework serves as the basis for this thesis research.

As GIS rose in popularity in the early 1990s, some scholars argued that GIS was leading geography back into a form of "naive empiricism" where facts and objectivity were replacing new knowledge formation (Taylor, 1990). Geographers such as Pickles (1995) and Sheppard (1993) were further concerned that the implementation of GIS was weakening geography as a discipline in that these systems were being used for high-tech displays of information and had little theoretical significance.

Proponents of GIS responded to the initial critiques of GIS by suggesting that many critics of GIS were reacting harshly only because they were afraid of change in the discipline (Clark, 1991). In a further response to some of the initial criticisms of GIS, 
major figures in geography defended GIS as more than just an extension of the quantitative revolution and more than just a new tool for data collection and visualization (Goodchild, 1991; Goodchild, 1995; Sheppard, 1993). Instead, scholars argued that GIS could be looked at as a science in which the major issues surrounding the use of GIS could be continuously examined and critiqued to improve GIS capabilities and to examine the impacts of GIS on society (Goodchild, 1995).

GIS and Society researchers argue that data used in GIS is a commodity due to the value of this information (Dueker, 1987; Mackay, 1982). Mackay notes that information is valuable because it reduces risk and uncertainty. Since access to data is valuable, Mackay argues that data will remain a commodity and will not be given freely and equably to all members of society. Mackay’s discussion about the commodification of data also recognizes that people who control the data are collecting it to answer certain questions. At the same time, Mackay cautions that many valid research questions are not being addressed because of limited access to pertinent datasets. Dueker and Mackay's early discussions about data equity and equality issues set up a major theme in the broadly defined GIS and Society framework.

Many researchers claim that more democratic uses of GIS can be achieved by giving groups access to GIS data, hardware, and software (Craig \& Elwood, 1998; Craig et al, 2002; Edney, 1991; Harris \& Weiner, 1998; Leitner et al, 2002; Openshaw, 1998). Oftentimes individuals and organizations with power and resources control information and the tools for accessing this information, which places those who do not have access at a disadvantage (Craig et al, 2002; Weiner et al, 1995). According to Taylor and Overton (1991), the first law of geographic information, which states that in areas where need for information is the greatest the amount of information is the least, also hampers democratic uses of GIS. This law of geographic information suggests that places that do not have access to information will be marginalized. Researchers within the GIS and Society framework call for broader access to geographic information and geo-spatial tools for analyzing information in order to ensure more democratic uses of GIS.

Understanding the social processes that create geographic information systems is an important theme under the GIS and Society conceptual framework (Aitken \& Michel, 1995; Craig et al, 2002; Harris et al, 1995; Lake, 1993; Obermeyer, 1998; Pickles, 1995; 
Sheppard, 1993; Taylor \& Overton, 1991). Some researchers argue that the construction of GIS is a social process in which people create systems of hardware, software, and geographic data to answer certain questions (Pickles, 1991; Taylor \& Overton, 1991). Pickles (1999) further suggests that the processes used to create GIS are value-laden and should be recognized as subjective. Recognizing that GIS are created through a social process, Aitken and Michel (1995) caution that the creators of these systems should not impose their own agendas on others through the technology.

By recognizing the role of a "hidden technocracy" (the companies that make GIS software available to the public) Obermeyer (1995) also stresses the social processes involved in creating GIS. Businesses that create GIS packages, Obermeyer argues, have the sole influence on what questions can be addressed with the technology. Obermeyer cautions GIS users to remember that GIS functionality is controlled by the hidden technocracy. As the above discussion highlights, it is important to remember that GIS are created through social processes in which the people who control the software, hardware, and data dictate which questions can be addressed using the technology.

Another theme under the GIS and Society conceptual framework suggests that GIS impose a certain way of thinking on the user (Sheppard, 1993). Sheppard compares GIS to the first universal Turing machine, which was limited to reading and writing symbols on a tape. The Turing machine could perform only one operation at a time, imposing a certain way of answering a question. Sheppard parallels GIS to the Turing machine because GIS impose one way of thinking on the user: Boolean logic. Sheppard suggests that the dominance of Boolean logic causes other logics to be marginalized, which severely hampers users who better understand other logic systems.

A GIS and Society conceptual framework also suggests that certain knowledge distortions occur due to the implementation of GIS (Taylor, 1991). According to Taylor (1991), a biased database occurs due to the values and objectives held by the person who creates the system. Taylor suggests that these biases create a structural knowledge distortion. Taylor also suggests that distortion can occur intentionally by people who hope to push their own agendas or because some types of data are difficult to represent in GIS. By challenging the subjectivity of GIS data and the representations of data included in GIS, Taylor and others show that GIS have some serious limitations. 
GIS and Society researchers also argue that the use of GIS raises serious ethical concerns and creates certain biases (Crampton, 1995; Curry, 1995; Dobson, 1993; Goss, 1995; Lake, 1993; Obermeyer, 1995). For example, geodemographic information systems organize extensive data about peoples' lives in order to predict consumer behavior. One serious implication of these extensive geo-spatial databases is that they can be crossreferenced by space and location to gain a detailed description of an individual's identity (Goss, 1995). Another ethical concern with data collection is that large datasets are collected; yet, people are often not allowed access to this highly personal information unless they pay for it. Crampton (1995) believes that individuals should be allowed free access to the personal data stored about themselves in GIS.

As discussed above, five major themes were born out of early critiques of GIS technology and now characterize a broadly defined GIS and Society conceptual framework. These themes suggest that: 1) GIS data is a commodity, 2) social processes create GIS, 3) GIS forces the user into a certain way of knowing, 4) ethics must be considered in using GIS, and 5) incorporating alternative epistemologies is important in GIS.

\subsection{Participatory Geographic Information Systems}

Research from the GIS and Society conceptual framework helped form a new body of literature entitled Participatory Geographic Information Systems, which explores issues related to GIS implementation (Abbot et al, 1998; Craig et al, 2002; URISA, 20022004). As PGIS researchers implement alternative epistemologies to geographic information systems, their research addresses five core issues (Weiner et al, 2002):

- The integration of both local qualitative information and expert knowledge in GIS

- The incorporation of multiple perceptions in GIS

- The use of participatory methodologies in GIS

- The issue of differential access to data and technology

- The relationship of GIS to local political and community contexts

It is important to discuss each of these core issues to better understand how PGIS researchers seek to improve the design and use of GIS. 
One of the core issues in PGIS research is the integration of qualitative information and "expert” quantitative data in GIS (Abbot et al, 1998; Craig et al, 2002; Harris \& Weiner, 1998; Obermeyer; 1998; Weiner et al, 1995). While traditional GIS data is needed for community projects, PGIS researchers argue that local knowledge held by members of the community is usually absent from traditional geographic information systems. Local knowledge of place and opinions from the community can be included in GIS to complement or strengthen existing geo-spatial information.

GIS users, researchers, and community groups suggest that there are ways to incorporate local knowledge with the formal, technical data already represented in GIS (Craig et al, 2002; Harris \& Weiner, 1998; URISA, 2002-2004; Weiner et al, 1995). In PGIS projects local knowledge is often collected through traditional public planning meetings, small focus groups, in-depth interviews, GPS transect walks, residential surveys, community mapping exercises, and 3D modeling and visualization techniques.

Incorporating multiple perceptions in a GIS is also an important area of research within Participatory GIS (Abbot et al, 1998; Craig et al, 2002; Leitner et al, 2002; Weiner et al, 1995). When soliciting information and opinions for community projects, researchers often find that many different perspectives exist. PGIS researchers argue that these multiple opinions and understandings of place must be represented in GIS to highlight the different views represented within a community. While every community member may have a different "reality," the strength of PGIS projects is that these projects often force community members with dissimilar views to work together in an interactive setting (such as a community planning meeting or a mapping exercise). These interactions often help to identify areas of potential consensus and contention between community members, while retaining the uniqueness of each participant's perspective.

A third theme of PGIS research is the integration of participatory methodologies into community projects (Al-Kodmany, 2000; Barndt, 2002; Casey \& Pederson, 2002; Elwood, 2002; Kwaku-Kyem, 2002; Leitner et al, 2002). Participatory methodologies such as transect walks, oral histories, and community mapping projects are implemented to provide traditional GIS with the intangible qualitative information held by people who 
live in the community and possess valuable insights, opinions, and perceptions about the community and local environment.

For example, researchers studying land and agricultural reform in South Africa used participatory methodologies to gather local knowledge about land reform (Weiner et al, 1995). These researchers argue that participatory methodologies are important because local knowledge cannot be fully understood by simply using traditional GIS data. According to Harris and Weiner (2002):

Much of a community's knowledge is heavily qualitative in nature and invariably based on oral history and the experience of having lived in a place for some time. Capturing this knowledge in a GIS that relies heavily on the spatial primitives of point, line, and polygon and the quantitative ordering of information is no easy task (247).

PGIS research also explores differential access to data and technology. Assessing the appropriateness of technology in community projects is vital to the success of a community GIS project (Craig et al, 2002). One pitfall of many GIS projects is that organizations often choose complicated GIS software and hardware, when a lowtechnology approach may in fact be more appropriate for community participation (Weiner et al, 2002).

For example, some PGIS researchers have implemented Internet-based data collection methods to integrate local knowledge into GIS (Alagan, 2003; Al-Kodmany, 2002; Carver et al, 2000; Krygier, 2002; Peng, 2001). While these systems help integrate local knowledge and provide another avenue for public participation, some researchers have argued that these high-technology systems inhibit participation for certain segments of society (mainly the poor and under-educated segments) (Craig et al, 2002; Elwood, 2002). Many community members do not have access to computers or the Internet and many also do not have the computer literacy necessary to effectively interact with these systems. Issues of technology access and computer literacy often make high technology systems, such as Internet-based GIS, inappropriate for many community GIS projects. Knowing that participation may be discouraged by high-technology systems, individuals often choose to implement low-technology methods for incorporating local knowledge in GIS (such as the low-technology participatory methods mentioned earlier in this chapter). 
PGIS researchers are also concerned with exploring the relationship of GIS to local political and community contexts. PGIS researchers note that the local political climate often has a large effect on the success or failure of community GIS projects (Craig et al, 2002; Leitner et al, 2002). Communities that have the money for GIS, have GIS capabilities, and have people knowledgeable of GIS often experience the most success with GIS projects.

A portion of the PGIS literature also stresses the importance of communityuniversity partnerships in local settings (Leitner et al, 2002). In these partnerships, universities provide students, facilities, hardware and software, and GIS expertise in hopes of assisting the community with its needs. Community members and groups provide universities with an avenue for entering the community, provide a vast amount of local knowledge, and provide individuals who are passionate about community issues. Together these two groups can form a powerful alliance where mutual needs can be met through action research or participatory research (Leitner et al, 2000).

As noted earlier, concepts found in the Participatory GIS literature come from earlier critiques within the broadly defined GIS and Society conceptual framework. PGIS researchers, operating mainly under the same conceptual framework as GIS and Society researchers, continue to critique the design and use of GIS in order to ensure that different community views and local qualitative information are included in GIS, to ensure that GIS are more democratic, and to ensure that GIS are not used for malevolent purposes.

\subsection{Land Use Planning}

In reviewing the GIS and Society literature and the Participatory GIS literature, it is learned that GIS and related geo-spatial technologies often play an integral role in land use planning. Planners, community groups, local governments, and universities use geospatial technologies to help answer questions surrounding local land use issues. It is important to review a portion of the land use planning literature that stresses public participation and then reflect on how geo-spatial technologies such as PGIS can improve public participation in local land use planning. 
Land use planners, much like PGIS researchers, argue that public participation can help strengthen community land use plans. While land use planners argue for increased public participation, these individuals also critically examine the roles and outcomes of public participation in land use planning. In this section of the chapter, various concepts related to land use planning are discussed, including: (1) the argument for more meaningful participation, (2) the concept of consensus building, and (3) the role of information in shaping arguments about critical land use issues.

Land use planners suggest that members of the public should be involved early in the planning process to make proposals better and to make these proposals more likely to be implemented in the community (Al-Kodmany, 2000; Brisbin \& Hunter, 2004; Brody et al, 2003; Burby, 2003; Coulson, 2003; Crewe, 2001; Day, 1997; Docherty et al, 2001; Fischler, 2000; Fleick \& Hall, 1999; Innes \& Booher, 1999a; Laurian, 2004). While it is important to involve the public early, it is also important to have the public participate in a meaningful way (rather than simply attending a public planning meeting). As one planner suggests, "what passes for citizen participation is simply going through the motions... and local efforts to involve stakeholders are symbolic rather than substantive" (Burby, 2003: 36). Some planners suggest that mandates should be imposed in cities and communities to ensure that participants are given many different opportunities to share their knowledge and opinions about local issues (Brody et al, 2003).

According to land use planners, consensus building is an objective of many community land use planning projects (Brisbin \& Hunter, 2004; Coulson, 2003; Day, 1997; Fleick \& Hall, 1999; Hanna, 2000; Innes \& Booher, 1999a; Laurian, 2004; Margerum, 2002; Zaferatos, 2004). The process of consensus building can be defined as "an array of practices in which stakeholders, selected to represent different interests, come together for face-to-face, long term dialogue to address a policy issue of common concern” (Innes \& Booher, 1999a: 412).

Effective consensus building can yield many positive results. First, stakeholders with varying viewpoints (who might not otherwise get together to talk about the issues) may come together and forge some common goals or proposals for land use planning in the community (Brisbin \& Hunter, 2004; Hanna, 2000; Innes \& Booher, 1999a; Innes \& Booher, 1999b; Laurian, 2004; Zaferatos, 2004). Since many different interests are often 
represented in consensus building efforts, these experiences often produce innovative ideas and solutions for land use planning. Residents also often gain some intangible benefits from the consensus building process. As Innes and Booher (1999a) note, consensus building efforts can form new relationships, greater levels of trust, and open communication channels between different members of a community. For example, participants, realizing that a specific land use issue is a problem for the entire community (not just themselves), might find ways to accommodate others' interests and modify their own interests to work towards a common goal of improving the community (Innes, 1996; Innes \& Booher, 1999b; Laurian, 2004; Zaferatos, 2004).

While consensus building efforts often yield positive outcomes for land use planning, attempting to reach consensus also has some disadvantages. One land use planner suggests that consensus building in community planning often leads to poorly worded proposals with little substance (Margerum, 2002). In trying to accommodate the views of different participants and interest groups, planners often use ambiguous wording to reach agreement and fail to define clear objectives. Land use planners also suggest that consensus building is problematic since some segments of society are excluded from planning (Innes \& Booher, 1999a; Innes \& Booher, 1999b; Talen, 2000; Ventura et al, 2002). Day (1997) contends that the results and objectives of consensus building efforts are often skewed by who participates. Docherty and others (2001) note that people choose not to be involved in land use planning because they distrust local officials, feel they cannot effectively change the outcomes, and have little time to become involved.

Land use planners also stress that many different types of information improve the effectiveness of community planning (Laurian, 2003). While newspaper articles and public meetings serve as ways to inform the public about critical land use issues in the community, these two sources of information are not sufficient (Laurian, 2003). As one planner notes, multiple sources of information can transform perceptions about the issues and significantly alter discussions held by community members (Hanna, 2000). In community planning projects, planners suggest that there are two different ways to deal with information. First, planners can provide information about local issues to the public (most often in a public meeting) in a one way process where planners share information and residents listen. Second, planners can engage in a dialogue with residents. 
Dialogues are two way approaches where planners and community residents voice their opinions, challenge each other's knowledge, and attempt to reach some form of consensus in regards to critical local issues (Hanna, 2000).

In an open dialogue or two-way approach to land use planning, multiple sources of information are used to define critical land use issues. Two types of information are pivotal to these two-way discussions: (1) scientific knowledge such as information obtained from GIS and remote sensing and (2) knowledge from participants' own experiences. While it is noted in the literature that scientific knowledge is often privileged in land use planning studies, anecdotal stories told by participants are beginning to carry more weight in community planning, since these stories reveal some land use changes that scientific knowledge cannot reveal (Al-Kodmany, 2002; Coulson, 2003; Zubrow, 2003). Innes (1998) suggests that more emphasis needs to be placed on qualitative methods in soliciting information from the public. In order to gather such information, planners need to sharpen their listening skills, conduct open-ended interviews, and learn to interpret the stories and experiences told by individuals.

According to one land use planner, a desirable public participation process allows citizens to share their knowledge about local issues, to shape planning and policy decisions, and to increase their social and political empowerment (Laurian, 2004). While land use planners stress the importance of involving the public in planning, many land use planners struggle to offer concrete suggestions for creating more meaningful opportunities for participation. Recognizing this shortcoming in land use planning, bridging this literature with Participatory GIS can offer helpful insights for land use planners as they attempt to integrate more meaningful public participation in planning.

\subsection{Bridging Participatory GIS and Land Use Planning}

In reviewing the Participatory GIS and land use planning literature, it is suggested that local knowledge and public participation are important aspects of community planning. In order to improve land use planning at the local level, both literatures suggest that more needs to be done to ensure that: 1) local participants are given meaningful opportunities for participation, 2) local qualitative information held by participants is given a more prominent role in land use planning discussions, 3) different people and 
interest groups work together in an attempt to reach consensus about critical community land use issues, and 4) all segments of society are encouraged to actively participate in planning.

Planners and local communities can use PGIS methods as they attempt to reach the four goals stated above. With the ability to analyze geographic data, visualize geographic data, and represent community viewpoints with spatial information, PGIS offer a highly effective visual communication, analysis, and representation tool for public participation in planning. Four case studies are discussed in the following paragraphs to help understand the different applications of Participatory GIS for encouraging resident participation.

Scholars at the University of Leeds in the United Kingdom provide many examples of web-based PPGIS applications for land use planning. One project from this institution entitled, "The Slaithwaite Public Participation Geographical Information System," was designed so that residents of the Slaithwaite village in West Yorkshire, UK could view a virtual model of the area and make suggestions about future village development. In this project, participants interact with and query a virtual GIS that links physical, environmental, and social information of the village to a map. As team members note, the project allowed "local communities to voice their opinions often through the use of a physical model which they can use to redesign, make suggestions and develop ideas about how they want their community to develop” (Carver et al, 2000).

A web-based PPGIS application for land use planning using images can be found in the Pilsner neighborhood of Chicago, Illinois. On a web site designed to collect public perceptions about local community issues, participants are able to view images of their neighborhood. An Internet sketch-mapping tool is used to survey local residents about their appreciation of specific areas in the community and these characterizations are incorporated into the GIS. This project allows communities to identify what is important and also allows them to include pictures in GIS to help visualize the physical context of their community in a way that is not typically possible using traditional GIS information (Al-Kodmany, 2000).

Talen (2000) uses Participatory GIS approaches for land use planning through Bottom-Up GIS (BUGIS), which helps communicate and visualize residents' perceptions 
of their neighborhood in a way that allows them to become the "expert." BUGIS approaches are used in a land use visioning project in the City of Dallas, Texas to introduce local community members to geo-spatial information for formulating a community revitalization and development plan along the Trinity River in downtown Dallas. Residents are able to view GIS information about the community and they are also able to integrate their own views into GIS for local land use planning. Planners worked with local community members to gain this information, map it in GIS, and help target areas that needed improvement and revitalization based on residents' perceptions of unsafe areas, infrequently visited areas, and disliked areas (Talen, 2000).

Planners in Dane County, Wisconsin use PGIS methods to give voice to underrepresented groups in local land use planning (Ventura et al, 2004). In the Dane County experience, land use planners use GIS maps to help understand what types of geo-spatial information are important to local community members and also to understand what areas should be designated for future residential development. Participation in this project occurs in small land use forums where participants are asked to delineate where future residential areas could be located on large maps. This project uses a PGIS methodology to include people who are impacted by land use decisions, but are often not given a voice in the land use decision-making process.

\subsection{Conclusion}

This chapter situates this thesis research within a broader GIS and Society conceptual framework and discusses the major components of Participatory Geographic Information Systems. The importance of and limitations to participation in land use planning at the local level are also discussed in the chapter. Learning from the literature on PGIS and land use planning, it is concluded that merging PGIS and land use planning at the local level can improve public participation in planning, incorporate residents' views of critical land use concerns, and provide awareness and education about critical land use issues to members of the general public. In situating the research within the broader literatures of Participatory GIS and land use planning, it is argued that a PGIS 
methodology can strengthen land use planning at the local level and move beyond the symbolic nature of participation present in the typical public planning meeting. 


\section{Chapter 3: Case Study and Methodology}

\section{Chapter Summary}

The case study area and a review of the methodology employed for this study are discussed in this chapter. The history of the Cheat Lake Planning District as told by a local historian is discussed in section one. The changing social attitudes towards land use planning in the study site are also discussed in section one. The Participatory GIS methodology and multiple participatory methods implemented are discussed in section two. The chapter ends with reflections on the PGIS methodology implemented.

\subsection{Case Study Area: The Cheat Lake Planning District of Monongalia County, West Virginia}

Historically, the Cheat Lake Planning District has served as a "bedroom" residential community with commercial and industrial development located in a few concentrated areas along major thoroughfares (Figure 3.1 below). The area known today as the Cheat Lake Planning District was settled around 1769 just before the Revolutionary War (Carvell, 2004). The National Road about thirty miles to the north and the area's timber resources were major catalysts for initial settlement in the area. According to local historian Ken Carvell, people travelling from the east used the National Road as a gateway to locations in Ohio, Indiana, and Illinois.

In the 1790s, the iron industry benefited from the introduction of the charcoal furnace. With this new development, the Cheat Lake area also thrived. In 1798 the first furnace (the Old Davies Furnace) was opened. According to Carvell (2004), the Cheat Lake area was an ideal location for the iron industry due to its abundant forests. Hardwood timber was essential for making charcoal, which could fuel the iron furnaces. While the iron industry thrived in the region, many people began to settle in the area. According to Carvell, locations to the west of the Cheat River (today's Cheat Lake Planning District) served as residential communities for workers in the iron industries located on the east side of the river. The iron industry thrived in the Cheat River area until about 1948 when competition from other places discovering better iron ore made it impractical for the iron industry to continue (Carvell, 2004). 


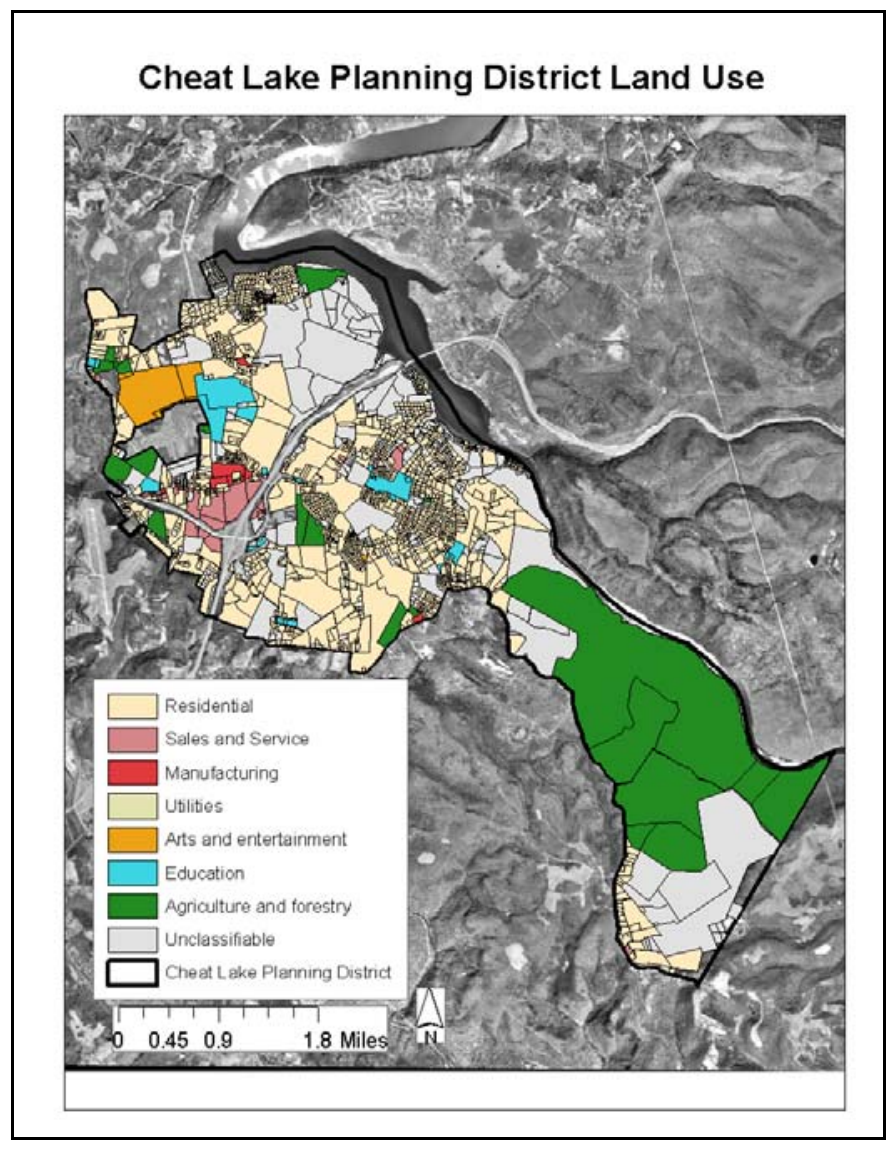

Figure 3.1 2004 Cheat Lake Planning District Land Use Classifications

A dam was built in 1911 to help control flooding and to create a hydropower source. Between 1925 and 1926, the dam closed and the Cheat Lake formed. By 1926 the newly formed lake helped make Sunset Beach the number one recreation place in the county. According to Carvell, "every teenager would be there all the time. I have pictures of the docks in Sunset Beach and there must be a thousand people standing out there having a good time.”

Increased accessibility resulting from the construction of Interstate 68 to replace U.S. Route 48 also helped develop the residential community and open the area to future commercial and industrial growth. With the impending completion of the Route 43 Expressway connecting Monongalia County to Fayette County (PA) in the neighboring Cheat Neck Planning District, county planners anticipate significant future development in the area, especially residential development in the Cheat Neck and Cheat Lake Planning Districts (Fletcher, 2005). 
Residents of the planning district have historically voiced strong sentiments against zoning and planning regulations in their community. Over the past decade as the area has experienced rapid demographic and environmental changes related to uncontrolled growth, many residents' opinions of zoning and planning have shifted as shown by one local historian's comments.

We all suffer from lack of zoning, but on the other hand the old families around here really, they are the ones that have kept zoning from coming in and that's true all over the county. They [the older families] didn't want someone to dictate to them how they could use their land. Many of them are regretting it now (Carvell, 2004).

The realities of unplanned growth in the area have led to growing subdivisions, increased apartment and condominium development, poorly connected developments, highly stressed transportation systems, and a deteriorating local ecology. Residents, now experiencing the effects of unplanned growth in the area, are calling on local government officials to enact planning and zoning regulations to prevent further unplanned development and environmental degradation in their community (CLPDAC, 2004).

The Cheat Lake Planning District Citizen Advisory Committee (CLPDAC), an organization of local community members committed to discussing future land use visions for the district, was formed in 2003 by the Monongalia County Planning Commission as part of its legal mandate to include public input in local land use planning (Fletcher, 2005). While members of the advisory committee have remained committed to fighting the negative effects of unplanned growth, past attempts at zoning and land use planning have failed for a variety of reasons. As many residents point out, an unresponsive county government, a former county planning commission that felt zoning was unnecessary, and a lack of public support for subdivision regulations prior to substantial growth led to stalled efforts in drafting subdivision regulations and zoning ordinances for the county and the Cheat Lake Planning District (CLPDAC, 2004). One comment from the July 2004 advisory committee meeting highlights residents' frustrations with failed attempts at zoning and unplanned growth: "we knew it would happen, but we did nothing to stop it. We needed some structure before growth happened." 
In the mid 1990s, county planners worked in conjunction with Cheat lake residents to create zoning regulations for the district; however, these plans failed due to poor design, a lack of direction from the former county planning commission, and an unsupportive residential population (Fletcher, 2005). According to one resident, the former county planning commission voted no on subdivision regulations ten years ago, which could have created zoning ordinances that may have lessened some of the negative impacts of growth and development in the area (CLPDAC, 2004).

According to committee members, many residents are not against development and growth in their community; rather, they are concerned with the types and rates of growth that are taking place. One resident at the July 2004 committee meeting stated "I am not opposed to growth, I am just opposed to the uncontrolled growth I see in this area...we should not be damaged by it [growth] in the process.” One resident concurred with this resident's comments saying "they [the developers] should do as we 'the community’ want to see and do it the way we want it done” (CLPDAC, 2004).

As the above discussion suggests, the historically residential Cheat Lake community has experienced rapid growth over the last decade. Faced with new problems from unplanned growth and troubled by failed attempts at zoning, members of the advisory committee are eager to see zoning regulations created for their community. To help the committee collect more public support for this process, this thesis research uses a Participatory GIS methodology with multiple methods to gain insights into community members’ critical land use concerns.

\subsection{Research Methodology}

Operating under a GIS and Society conceptual framework and recognizing the importance of communicating and visualizing the multiple experiences of place, this thesis research employs a Participatory GIS methodology using multiple methods, including:

- In-depth key informant interviews

- Focus group discussions

- Participatory mapping

- GIS mapping and overlay 
- Participatory GIS multimedia integration

In this thesis research, a Participatory GIS methodology is implemented to help understand and map community members' opinions of the community and local land use concerns. This thesis research adds information held by the community into the planning process, which otherwise would not have been as prominent in local planning and zoning discussions. This information also helps the advisory committee gain public input and support as they lobby for land use planning and zoning regulations.

\section{The Public (Re)Shapes the Research Agenda}

Operating under a GIS and Society conceptual framework and using a Participatory GIS methodology, a PGIS with community local knowledge was designed for the study area. As discussed in the PGIS literature review found in chapter two, key (and often overlooked) components of many participatory projects are: to allow the community to define their own needs, to work in conjunction with them to develop products (in this case a PGIS of the study site and a final report of major community issues), and to help represent, communicate, and visualize these needs to other members of the community including government officials.

Recognizing that PGIS research should be driven by a specific community need, the Cheat Lake Planning District PGIS was created in conjunction with the Cheat Lake Planning District Advisory Committee. In the summer of 2004, the committee met with WVU geographers to identify their major concerns about land use and unplanned growth. At this initial meeting, each participant was given an opportunity to talk about his or her top issues in the planning district. After listening to each community member share his or her opinion about land use problems, some common themes were identified. Residents were most concerned with overdevelopment and subdivision growth in their planning district. According to residents at the meeting, overdevelopment and subdivision growth were also causing other problems, including: flooding, habitat destruction, overcrowded schools, traffic congestion, and insufficient utilities to serve the growing community.

From this initial meeting with concerned local residents, it was determined that the WVU research team could help the advisory committee learn more about the community's opinions of growth related issues. The team was responsible for mapping and identifying particular geographic hotspots where growth related problems were 
occurring. This community information in the form of documented narrative and mappable information was then used by the committee to show the county planning commission that particular hotspots exist in the district.

After meeting with the CLPDAC, the WVU research team reworked its original objectives for the community participation portion of the project. Instead of testing shifting perceptions of land use and land cover change before and after exposure to digital data of the planning district, the research focus shifted to meet the pressing needs of the community as defined by committee members. As discussed in the literature, "qualitative researchers are encouraged to allow the research situation to guide research procedures in order that they may gain access to human experiences” (Baxter \& Eyles, 1997: 506).

\section{The Cheat Lake Planning District Participatory GIS Approach}

To gather information requested by the CLPDAC, the team planned an exercise that could collect and map community knowledge of land use concerns. This information was collected in order to strengthen public participation in local land use planning and also raise awareness about land use issues in the community. The research team gained access to participants in the Cheat Lake Planning District by working in conjunction with the advisory committee to identify both key informants and places where focus group discussions could occur.

\section{Qualitative Approaches for Participatory GIS}

Geographers use qualitative methods to understand individuals’ experiences with place (Dunn, 2000; Winchester, 2000). Winchester suggests that individuals experience places and events differently; therefore, it is important that individuals are given an

opportunity to recount these experiences (Winchester, 2000). Qualitative methods, used to help complement information collected through quantitative approaches, help represent these multiple viewpoints and individual experiences:

The goal (of qualitative research) is not to produce a standardized set of results that any other careful researcher in the same situation or studying the same issues would have produced. Rather it is to produce a coherent and illuminating 
description of and perspective on a situation that is based on and consistent with detailed study of the situation (Ward-Schofield, 1993: 202).

Qualitative methods allow participants to voice their opinions and perceptions in a way that other methods may silence or fail to capture (Winchester, 2000).

Sampling plays a significant role in qualitative research methods. While quantitative approaches generally stress the need for random sampling, qualitative approaches typically use purposeful sampling techniques, which attempt to find participants who hold a significant portion of information about the research questions (Baxter \& Eyles, 1997; Cameroon, 2000). Qualitative researchers are more concerned with understanding "meanings in specific contexts" rather than gathering "representative" samples (Bradshaw \& Stratford, 2000: 45). Purposeful sampling in qualitative research is intended to explore meaning in specific contexts until no new themes are brought out in discussions with participants. Determining the proper sample size for qualitative research is based on redundancy and saturation, rather than statistical representativeness (Baxter \& Eyles, 1997). Each of these sampling issues was considered when conducting key informant interviews and focus groups in the Cheat Lake Planning District.

It is important to recognize that the PGIS methodology used in this research is biased towards residents who choose to participate or those who feel strongly about zoning and planning issues; therefore, the methodology is limited in that it cannot be characterized as representative of the entire Cheat Lake Planning District population. While this is one minor drawback to the research, these biases are in fact similar to biases that occur in typical planning processes where supporters and opponents with strong opinions come out to voice their opinions, while the majority of the population chooses not to attend.

This research recognizes the inherent limitations of collaborative planning efforts. However, the methods used in this study do offer many benefits to local planning, including: 1) bringing more participants and ideas into the discussion, 2) raising public awareness about land use issues in the community, 3) creating opportunities for participants to engage with geo-spatial information to help visualize their land use issues, and 4) improving communication between government entities such as the planning 
commission and members of the community who do not generally participate in local planning.

\section{In-depth Interviews with Key Informants}

In-depth interviews are content-focused conversations with key informants who have lived in an area for an extended period of time or who have knowledge about a certain subject of interest (such as land use concerns in this thesis research) (Arksey \& Knight, 1999; Dunn, 2000; Siedman, 1998). The experiential knowledge of place collected from in-depth interviews may not be evident when using other analytical methods, such as surveying or analysis of census data (Dunn, 2000). Individual interviews with knowledgeable members of the community help strengthen research projects through the collection of a diversity of opinions from community members with different areas of expertise. Information gathered from in-depth interviews can help to identify areas where agreement and difference in opinion may occur between different groups of people (Dunn, 2000).

Individual interviews with key informants help complement information collected from traditional quantitative surveying techniques. In-depth interviews allow researchers to understand which issues are most important to the participant, as opposed to research methods that focus on researcher-defined questions to test a hypothesis (Dunn, 2000). Individual interviews empower participants by giving them the opportunity to reflect on their experiences more in-depth than is possible with quantitative surveying techniques (Dunn, 2000; Seidman, 1998).

For this project, the planning district advisory committee and the county planner identified key informants (Table 3.1 below). Two types of key informants were identified for this study: (1) members of the community who have lived in the area for an extended period of time (over 20 years) and know about the local history and (2) members of the community who were identified as "experts" in a particular topic that could help understand planning and development problems in the area. These interviews were conducted in the informants' place of residence or place of employment and helped gain information about specific issues in the Cheat Lake Planning District. 
Table 3.1: Cheat Lake Planning District Key Informants

\begin{tabular}{|l|l|}
\hline Key Informant & Field of Expertise \\
\hline Ken Carvell & Local History and Local Ecology \\
\hline Christopher Fletcher & Land Use Planning \\
\hline Allen Judy & Local Residential History \\
\hline Chet Parsons & Transportation Planning \\
\hline Jim Rye & Alternative Transportation and Local Ecology \\
\hline
\end{tabular}

\section{Focus Group Discussions}

Focus groups, much like key informant interviews, are a qualitative approach where researchers can learn a significant amount of knowledge that may not be evident through quantitative approaches or surveying. Small focus groups allow group discussion that provides valuable insight into the social relations and characteristics of a particular place (Goss \& Leinbach, 1996). The “'stories' produced in the collaborative performance of a focus group better reflect the social nature of knowledge than a summation of individual narratives extracted in interviews” (Goss \& Leinbach, 1996: 115). As Bedford and Burgess (2001) suggest, the collaborative nature of focus group discussions allow participants to share and challenge the knowledge of others while also testing their own assumptions of place. Goss and Leinbach further note the power of focus group discussions:

Focus groups give the participants an opportunity to narrate their personal experiences and to test their interpretations of events and process with others, and whether confirmed or disputed, the result is a polyvocal production, a multiplicity of voices speaking from a variety of subject positions (Goss and Leinbach, 1996: 118).

Focus groups held to discuss community members' views on a particular issue help raise further questions about a particular issue (Goss \& Leinbach, 1996). Focus groups are empowering to the individual because these group discussions are often the first time participants are given an opportunity to speak publicly about their opinions. 
According to Goss \& Leinbach, "the main advantage of focus group discussions is that both the researchers and the research subjects may simultaneously obtain insights and understanding of particular social situations during the process of research” (1996: 116117).

In this study, the advisory committee and the county planner identified areas where focus groups could be hosted (Table 3.2 below). From a 2004 map of the Cheat Lake Planning District, it was determined that five to seven focus group meetings could be held in different geographic and demographic areas in the planning district.

Table 3.2 Cheat Lake Planning District Focus Groups

\begin{tabular}{|l|l|l|}
\hline Focus Group Participants & Meeting Location & Attendees \\
\hline Canyon and Canyon Rd. & Church & 15 \\
\hline Canyon and Canyon Rd. & Church & 8 \\
\hline Tyrone Avery Road & Local Home & 8 \\
\hline Meadowbrooke & Local Home & 5 \\
\hline CLPDAC & County Airport & 3 \\
\hline
\end{tabular}

In areas with homeowners associations, the president of the association was identified as the key contact and responsible for inviting other residents to the discussion. In areas where no homeowners association was present, the county planner and the advisory committee identified key contacts. Areas that were not identified as subdivisions on the map were also included in focus group discussions. For example, the local community of Canyon was determined as an important area to hold a focus group discussion, yet it was not recognized as a subdivision. Community and neighborhood gatekeepers were responsible for inviting others to the discussions. Focus groups were conducted in a community member's home or at a local gathering place (such as a library or church) identified by the local contact. 


\section{Gathering a Community’s Local Knowledge through Participatory GIS}

Three open-ended questions were designed for discussion to help gain information for inclusion in the Cheat Lake Planning District Participatory GIS. The first open-ended question asked participants to: "Please discuss and locate any areas on the map that you feel are current land use concerns.” This question was designed with three objectives: (1) to generate a discussion about overall land use concerns in the district, (2) to have participants spatially locate where particular land use concerns were prominent, and (3) to identify common themes that could be summarized for the public participation requirement in the county’s land use planning process.

The second open-ended question asked participants to: "Please discuss and locate on the map any areas that you feel should be protected or preserved for the future." This question was asked to learn where community members felt existing open spaces and large parcels could be protected and prioritized for future planning and zoning regulations. A third open-ended question asked residents to: "Please discuss and locate on the map where you would like to see certain types of development encouraged in the future." This question attempted to find out what residents believed the future vision for the planning district should be and also attempted to identify where particular land uses could be encouraged in the future.

Each of the three questions was born out of discussions between the CLPDAC and the research team. The questions were designed in an open-ended manner to encourage discussion of individuals' desires and needs. The research team did not feel it would be appropriate to create a detailed survey with specific questions, since these types of questions could shift participants' thought processes to an outcome that would fit predetermined hypotheses. Instead, through open-ended questions and a participatory mapping exercise crafted from discussions with the advisory committee, the research team hoped to encourage participants to lead the discussion and take the team on a journey that explored and represented participants’ views and concerns.

The participatory mapping exercise, which was used during key informant interviews and focus group discussions, was completed on tracing paper draped over two 1:7,000 meter scaled maps of the Cheat Lake Planning District. A map of the planning district north and west of Interstate 68 (a major interstate that essentially cuts the district 
in half) and a map of the planning district south and east of Interstate 68 were created to provide participants with sufficient detail of the area for mapping purposes. The maps included 1997 black and white aerial photography, planning district boundaries, three landmark identifiers (the Glenmark Centre, the Cheat Lake Elementary and Middle Schools, and the WVU Farm), and three major roads (Canyon Road, Tyrone Avery Road, and Tyrone Road) so that residents could spatially orient themselves while using the maps.

\section{Participatory GIS Mapping and Overlay}

From discussions with the planning district advisory committee, it was determined that geographic land use hotspots, preservation areas, and future visions should be discussed with local community members and also mapped in a Participatory Geographic Information System. To accomplish this task, multiple GIS layers were created in an ArcGIS 8.3 environment. Separate layers for points, lines, and polygons were created. Each layer contained features that represented common themes identified by the CLPDAC and participants. The point layer contained only one specific feature: traffic concerns (dangerous intersections and bottlenecks). The line and polygon layers each contained six specific attribute codes (Table 3.3 below) for each individual land use theme.

Table 3.3 Participant Defined Themes for Line and Polygon Layers in PGIS

\begin{tabular}{|l|l|}
\hline Attribute Code & Community Defined Theme \\
\hline 1 & Overdevelopment \\
\hline 2 & Flooding \\
\hline 3 & Infrastructure \\
\hline 4 & Ecological concerns \\
\hline 5 & Schools \\
\hline 6 & Future Visions \\
\hline
\end{tabular}

Based on discussions with participants, theme one (overdevelopment) was also further broken down into three specific types, including: rapid subdivision growth, townhouse and apartment development, and density issues. Theme three (infrastructure) 
was divided into four subclasses, including: roads, water, sewage, and fire protection. Theme six (future visions) was also broken down into smaller subclasses, including: future residential areas, future large commercial development areas, future small-scale commercial development areas, and future preservation areas.

Each of the above community-defined themes was manually digitized in ArcGIS from maps drawn by participants. From transcripts of discussions with participants, textual attributes were added into tables for the PGIS. Place labels, key characteristics, and narratives about specific locations were included within the tables for each theme.

In order to make a more effective visual communication tool (Al-Kodmany, 2001; Weiner et al, 2002) for later use in local land use planning discussions, multimedia was also integrated into the Cheat Lake Participatory GIS. To accomplish this task, hyperlinks were created in each attribute table for specific areas identified by participants. Textual narrative, photography, video, sound, panoramic photography, and websites with information about specific land use concerns were included in the PGIS. Members of the advisory committee and the county planner stressed the importance of this multimedia display, noting that it could be a powerful visualization tool for future education of the problems facing the community.

\subsection{Conclusion}

The Cheat Lake Planning District (a historically residential community) is experiencing rapid growth with subsequent changes in land use. The planning district advisory committee and other community members are now calling on local government officials to create zoning regulations for their community. A Participatory GIS methodology designed to aide the CLPDAC in representing community members' critical land use concerns is discussed in this chapter to help show how geo-spatial technologies can assist with land use planning. 


\section{Chapter 4: Results and Discussion}

\section{Chapter Summary}

Five major results of the research process and an examination of how these results relate to the main themes of Participatory GIS and land use planning are discussed in this chapter. Figures documenting results of the PGIS process are also discussed in section five to demonstrate what the PGIS methodology adds to land use planning in the Cheat Lake Planning District.

Five major lessons were learned from building a Participatory GIS for residential participation in the Cheat Lake Planning District as part of this thesis research. Results of the PGIS process suggest that: (1) PGIS can strengthen public participation in local land use planning, (2) local political context leaves residents reluctant to get involved in a PGIS project, (3) PGIS can answer academic research questions, but it can also be designed to answer a community’s critical questions, (4) the "story telling” involved in PGIS can serve as an empowering tool for participants, especially those who do not typically participate in local planning, and (5) PGIS can yield tangible products that identify critical community themes and concerns.

\subsection{PGIS for Increased Participation in Local Land Use Planning}

Research done in the Cheat Lake Planning District suggests how a collaborative PGIS project can aide local land use planning agencies in meeting their legal mandate for public participation. Recalling the discussion in chapter two of this thesis, which suggested that efforts to involve members of the general public in planning are often symbolic rather than substantive, results of this research suggest that a PGIS methodology can yield more substantive opportunities for participation in local planning than the more symbolic public meeting. In this research, participants are given an opportunity to engage in open-ended discussions about their critical land use concerns, map these concerns, and create "expert" spatial information for inclusion in future planning discussions in a way that moves beyond the symbolic participation found in larger public meetings. As the county planner suggests, PGIS allows the advisory committee to gain the insights of local residents in a way that goes beyond what the 
committee and the planning office can accomplish given the local political context and the budgetary constraints of the planning commission.

\subsection{Impact of Local Political Context on the Cheat Lake Planning District PGIS}

Results of the Cheat Lake Planning District research experience also suggest that local community members are hesitant to get involved in a collaborative research project due to past political failures at the local level. As Ghose and Huxhold (2001) suggest, local political context plays an important role in the direction of and participation in the PGIS process. In this particular research, the WVU team had to overcome residents' negative reactions to local political context, which included numerous past planning failures. As many residents pointed out early in the research, an unresponsive county government, a former county planning commission that felt zoning was unnecessary, and a lack of public support for zoning regulations prior to substantial growth led to stalled efforts in drafting zoning regulations for the county and the Cheat Lake Planning District. One comment from the July 2004 advisory committee meeting highlights residents' frustrations with failed attempts at zoning: "we knew it would happen, but we did nothing to stop it. We needed some structure before growth happened.”

At the July 2004 meeting, residents recounted previous planning efforts held by a consulting firm that had them map future visions for the community. CLPDAC members worked in conjunction with these consultants to share their land use concerns, yet no tangible results came from the participatory process. Committee members were frustrated at these past failures and asked: "how could we trust them [the consultants] when they didn’t even know how to pronounce our county's name?” These past failures at the local level made the WVU research team's involvement in the new collaborative planning effort difficult at first. Recognizing the local political context that included past community mapping failures, residents were skeptical of what a collaborative PGIS could do for them and were also reluctant to join in a collaborative PGIS project without having a major say in shaping the direction of such a process. 


\subsection{Merging Academic Questions and Community Questions through PGIS}

This thesis research suggests that despite a community's negative reactions to local politics, participation in and acceptance of a PGIS can occur if the project is shaped to answer the community's critical questions, rather than academic research questions. As Harris and Weiner (2003) suggest, PGIS research emphasizes stronger community participation and local knowledge integration into pivotal human-environmental interaction discussions. With this in mind, this thesis research merges academic research questions with a community's critical issues in order to improve participation and community input in local land use planning.

In this project, the research team first approached members of the planning district advisory committee with a vision for integrating geo-spatial technologies in local land use planning, which involved collecting land use and cover change information from various time periods and then testing residents' perceptions of these changes. At the July 2004 advisory committee meeting, community members voiced strong opposition to this proposed research direction noting that (1) they already knew what types of change were occurring in the district and (2) GIS information was not necessary to confirm what they knew was already occurring. Instead, members of the community suggested that the university's research efforts could be more beneficial to the advisory committee if the team explored and mapped the types of growth occurring in their community and particular hotspots related to this growth.

CLPDAC members expressed a desire to have a voice in shaping the future planning agenda; therefore, the team's research efforts shifted to assist the group in finding answers to their critical questions. One community member noted at the July 2004 advisory committee meeting that: "they [the developers] should do as we "the community' want to see and do it the way we want it done.” Instead of a complex land use and cover change analysis that tested perceptions about land change before and after exposure to geo-spatial information, the research team altered their goals and implemented a field-based PGIS approach that emphasized group discussion and participatory mapping to answer questions that the CLPDAC felt could be beneficial in local land use planning. 


\subsection{Empowering Marginalized Communities through PGIS}

The research process also suggests that the "spatial story telling” (Aitken, 2002) involved in collaborative PGIS can have an empowering effect on local communities, particularly for those that feel marginalized, unimportant, or left out in local planning initiatives. One of the strengths of this research is that local community members are given an opportunity to voice their land use concerns in a way that is not typically possible in the top-down public meeting. As it is well-documented throughout the broader land use planning literature (see chapter two) and more specifically at the local level by the county planner, public planning meetings are often poorly attended. This research allows more community members to participate earlier in the planning process and in a more meaningful manner by sharing land use concerns through a discussion and mapping exercise.

As a result of this thesis research, marginalized communities that have had historically low levels of participation in local planning were encouraged to participate and share their views for inclusion in the broader land use planning discussion. For example, focus group discussions held in the once thriving coal mining area of Canyon highlight the power of the collaborative PGIS process. As noted by the county planner and by one advisory committee member who lives in Canyon, members of this area typically do not get involved in planning, because they feel they can do little to change the outcome. Through this research, two focus group discussions were held in this lower income community to learn about its history and its land use issues. These discussions proved empowering to members of the community. Residents were given the opportunity to be the "expert" on the history of their community through recollections of the past and photographs. Residents were also given the opportunity to map their community and its land use concerns in a way that valued their comments for later consideration in the planning process. Throughout the meeting with community members, residents were able to talk openly to the research team and also felt empowered by the experience, as suggested by one participant's comment: "we appreciate that you came out and talked to us, it is not often that someone comes out to get our opinions and learn more about the history of the area.” 


\subsection{Identifying and Mapping Critical Community Themes with PGIS}

The collaborative PGIS process also yielded some tangible results in the form of a PGIS of land use themes defined by members of the community. Both members of the planning district advisory committee and project participants discussed and mapped a variety of land use concerns, including:

- Overdevelopment and Increasing Housing Densities

- Clear Cutting for New Development

- Flooding Hotspots

- Transportation and Traffic Concerns

- Potential Preservation Areas

- Potential Recreational Trails and Walkways

This information, along with multimedia of specific concerns, was included in a PGIS to help visualize the severity of these problems and to start a discussion about planning and zoning regulations.

\section{Overdevelopment Concerns and Increasing Population Densities}

As members of the advisory committee and the county planner argued at the beginning of this project, new housing subdivisions and apartment complexes have been spreading throughout the planning district due to a lack of zoning regulations, the county's population expansion, and the growth of WVU. Through the PGIS process, residents also pointed to subdivision growth and housing density issues as two major catalysts of land use problems. Figure 4.1 (below) shows subdivisions present in the district and also includes photographs of some housing density issues expressed by project participants. Figure 4.1 and the narrative below highlight the concerns residents have about rapid and unplanned growth in the planning district. One key informant (Key Informant \#2, November 2004), responding to a question about land use, summarizes the growth problems evident in the area:

Things are happening quickly now. In the first five years I was living here, there really wasn't much development, but now for some reason or another (and I think part of this has to be with the growth of the university) there is a lot of overbuilding. People will still continue to move here and want to live here while we still have this partial rural atmosphere, but at some point with all the overbuilding it's going to become another Pittsburgh. 
Participants in another focus group discussion (Focus Group \#2, December 2004) also highlight the overdevelopment problems facing the planning district and suggest that these issues can be addressed by citizens and county officials through zoning and planning regulations:

One has to perceive from the point of knowing where there is a potential good for development. [Developers] are building on slopes that are ridiculous and for them it just happens...it's a matter of business. Is that wise development? We probably could point to a number of factors to say it's not, but they [the developers] are going to do it anyway. In terms of zoning we [residents and county officials] have to be able to say [to developers]: 'that's a really crazy place to do it [develop]. Can't you do it somewhere else? There are other places in the county and in the area where it would be more appropriate.'

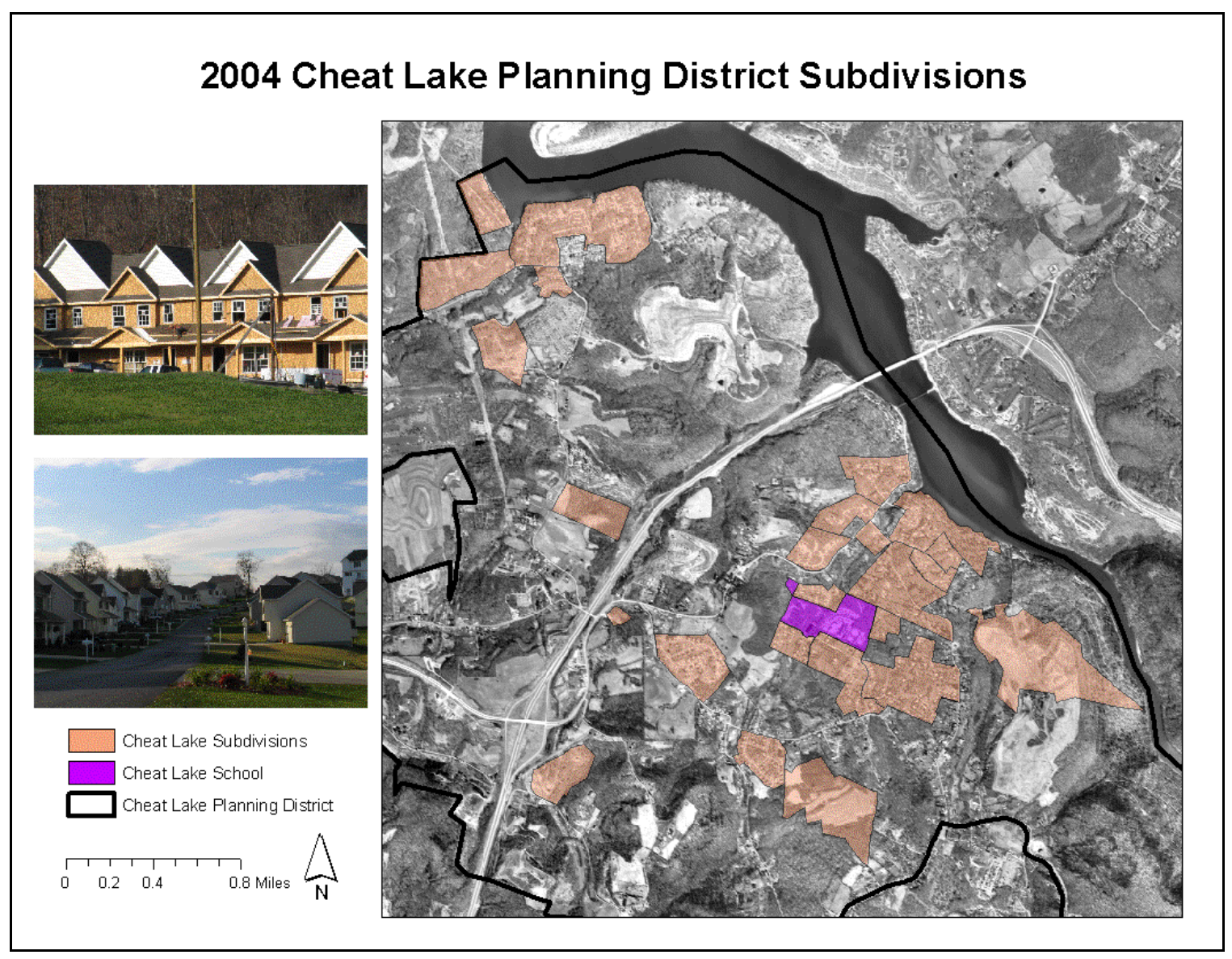

Figure 4.1 2004 Cheat Lake Planning District Subdivisions 


\section{Concerns about Clear Cutting for New Development}

Residents also expressed concern that large parcels, which were once green space, woods, or farmland, are being subdivided for high-density housing and apartments. Comments from one focus group discussion (Focus Group \#3, December 2004) summarize this community-defined land use concern:

Developers are raping the land for their personal profit and it's just not right. For example, the new development along Turtle Creek has a bunch of houses and apartments on a large piece of land that once had only two or three houses on it. Right now developers have a market here and there's no reason for them not to do what they are doing now...unless they feel bad in their hearts.

Comments from another focus group discussion reiterate statements about clear cutting mentioned by other participants. One resident states that: "all I have to do is stand in my front yard and I can see that all they [the developers] are doing is stripping the hillside away." In response to these initial comments about overdevelopment and clear cutting, another resident claims: "we have a tree problem in the Cheat Lake area. Not that we have too many trees, but that developers are building houses right on top of the trees. This is unacceptable!” The comments above suggest that participants are concerned with the amount of development and clear cutting occurring in the planning district. Representing this land use concern in a PGIS for the study site became an important component of this research.

\section{Flooding Concerns}

Residents who participated in the PGIS process also suggested that flooding is a critical issue throughout the planning district. One resident's story of flooding serves as an example of the burdens residents face in the CLPD:

The neighbors across from my house (an 83 year old man and a 79 year old woman) get water from the Deerwood subdivision every time it rains. I get very upset when I see them in their front yard cleaning up water. They shouldn't have to deal with that...it is preventable!

Adding to this participant's comments about flooding, one resident notes that after one heavy downpour: "the flooding was so bad in my front yard that it took me four days to shovel all the mud and dirt out of my yard from the storm runoff. Flooding is such a problem that the first thing my wife does every morning is turn on the weather channel.” 
Comments from another focus group discussion also highlight flooding concerns. One participant said to the research team: "if you want to go and look at ours [flooding] in the backyard, it's pretty much like a ditch and it has running water in it and it's never stagnant. Since we've moved here about a year ago, the water from the creek has gone over the banks, washed down the street and also flooded our yard.” A participant in this focus group discussion added that the flooding problem was a result of "a development that is a pretty goods ways up stream." A participant in another focus group discussion (Focus Group \#4, March 2005) also confirmed what others were saying about flooding:

In our neighborhood [Imperial Woods], we have solid mud coming off of a disturbed area that has been recently clearcut for future development. We have heard that a block of condos are to be built on this site and we are concerned since we are flooded and because the stream has literally disappeared. Meadow Lane is being flooded out!

In addition to identifying particular flooding hotspots and voicing frustrations about flooding, residents also stressed that flooding has worsened over the past few years as development has increased and the natural storm water drainage has become overburdened. According to one resident (Focus Group \#4, March 2005), a potential reason for increased flooding is related to culvert size:

The size of the culverts is a problem with the amount of rain we have. We have lived here for 25 years in the same house and until last year we had never experienced the kind of problems we do now... a lot of things have changed and a good portion of it is because we have a lot more developments here in this area than there was 25 years ago.

As documented above in comments made during the PGIS process, participants identify flooding as a major land use issue. In addition to discussing flooding, many residents chose to draw flooding hotspots during the participatory mapping exercise. Figure 4.2 (below) highlights a composite map of flooding hotspots, which is included in the PGIS. Figure 4.3 (below) shows a close-up of an often-mentioned flooding hotspot with narrative describing why flooding occurs in this area. 


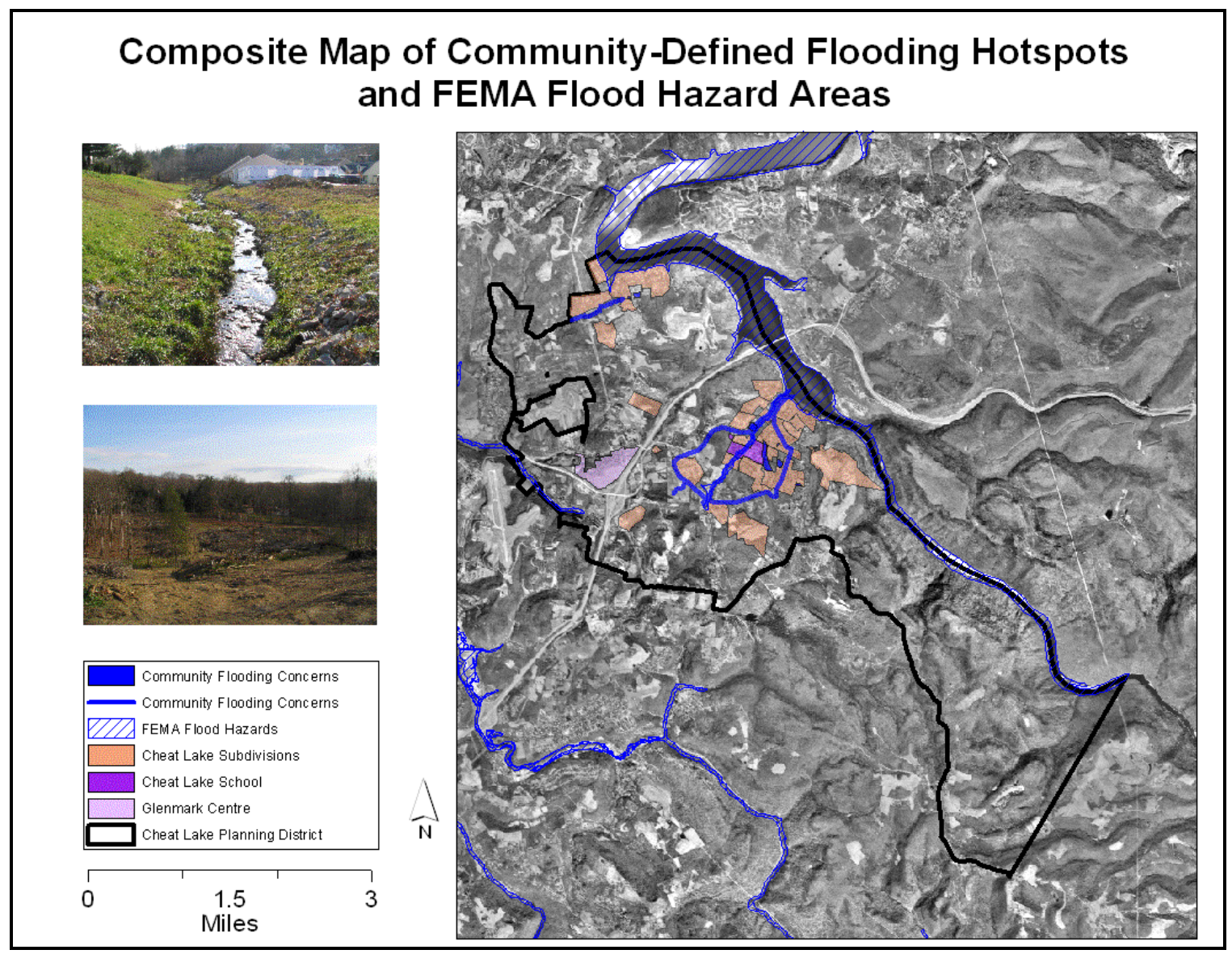

Figure 4.2 Composite Map of Community-Defined Flooding Hotspots and FEMA Flood Hazards 


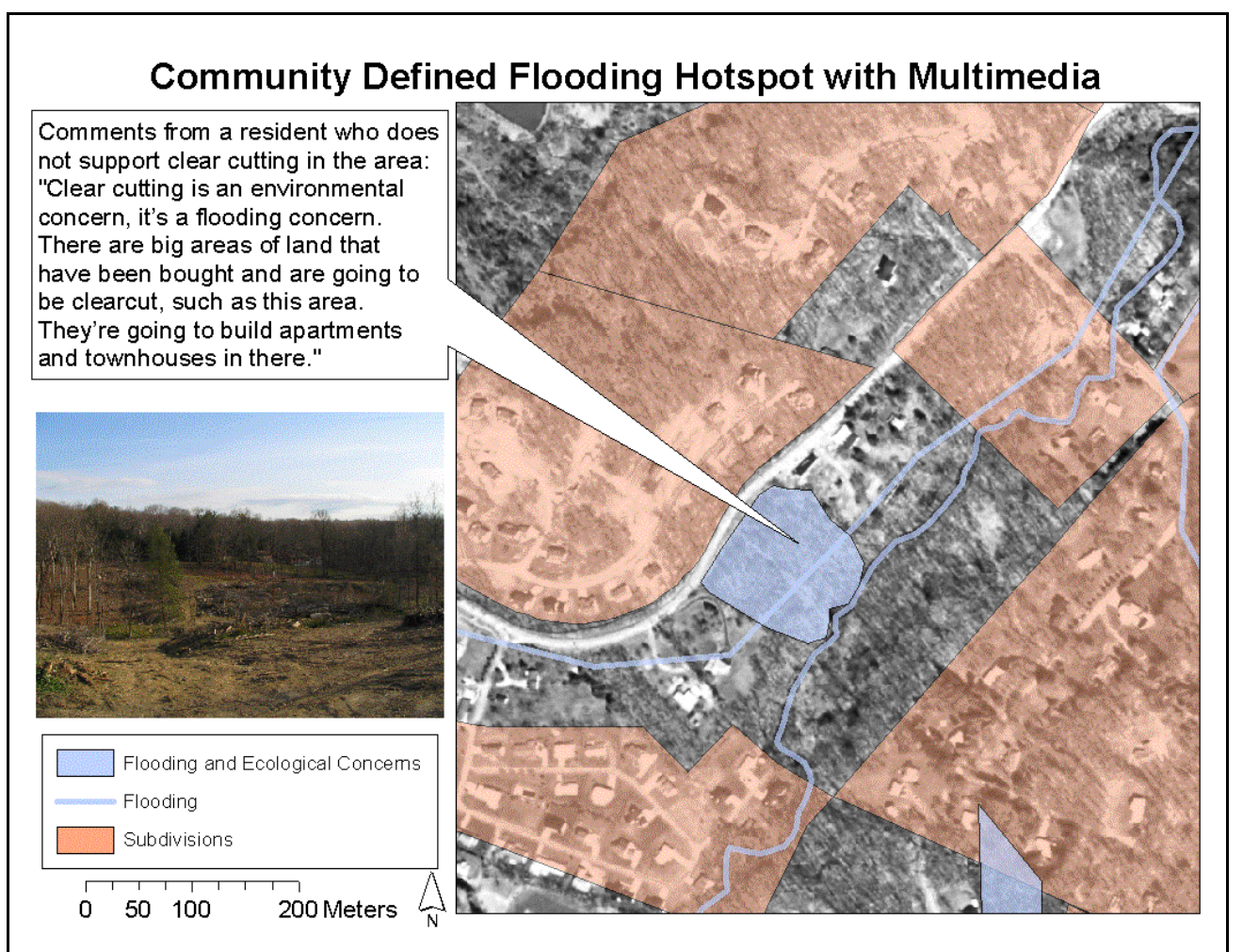

Figure 4.3 Community Defined Flooding Hotspot

Figure 4.2 (above) also shows flood hazard areas as defined by a 2004 FEMA mapping project. It is important to note that the community-defined flood hazard areas shown in Figure 4.2 extend beyond what is included on the FEMA flood maps. One outcome of the PGIS process is that the community-defined flood information included in Figure 4.2 can be combined with existing FEMA geo-spatial flood data to better represent flood risk in the planning district. According to FEMA, a detailed study of the area was last conducted in 1994. Given the significant development and land changes in the area since 1994, it is highly probable that flood risk has increased. The community local knowledge about flooding gathered from this study will be used by the county planning commission as evidence to encourage FEMA to restudy the area.

In addition to mapping flood hotspots, participants also stressed that local officials must address flooding issues. The following focus group discussion highlights this desire. One participant began by noting that: "one of the things I read about in the paper is that developers were being able to work without doing any kind of work to prevent flooding downstream from what they were doing. I heard that that was going to change.” Another resident noted that: "the only thing they [developers] have to do is call the county 
planning office and make sure they're not in a flood plain, which is very vague.” A third resident responded with a question and a comment: "so, someone that is building a lot of houses up the hill and is not in a flood plain doesn't have to worry about the fact that they are causing all kinds of runoff? That's not right.” This focus group discussion suggests that residents are concerned with flooding issues in the community and want local officials to enact regulations to prevent future flooding occurrences.

\section{Transportation and Traffic Concerns}

Residents also discussed transportation concerns during the PGIS process by identifying dangerous intersections, traffic bottlenecks, and stressed roadways. It was suggested in one focus group discussion that: "the roads are in terrible condition and are not keeping up with the new developments. It only makes sense that if more subdivisions are added to the Cheat Lake area, then new bigger and better roads should also be added to accommodate all these new people.” A key informant's comments also document the severity of transportation and traffic concerns:

When I moved here ten years ago, where Tyrone Avery hits 857, even at quarter to eight in the morning, which is the time everybody is going to work, there were maybe two or three cars. Now, at that same time I wouldn't even want to go near that area because there is so much traffic. Traffic is a big issue and increasingly the air quality [related to traffic] will become an issue. When cars are in traffic jams they tend to burn less efficiently.

Figure 4.4 (below) highlights the composite map of traffic concerns compiled from the participatory mapping exercises. This geo-spatial information collected from the community can be integrated with existing traffic count data to highlight traffic hotspots and prioritize roadway improvements. Unfortunately, due to data sharing agreements with the private company who collected traffic count information for the county planning office, this expert information was not able to be included in the PGIS. However, the county planning office plans to integrate the community-defined transportation concerns into their existing GIS with expert traffic count information to highlight critical transportation concerns and prioritize transportation funding in the planning district. 


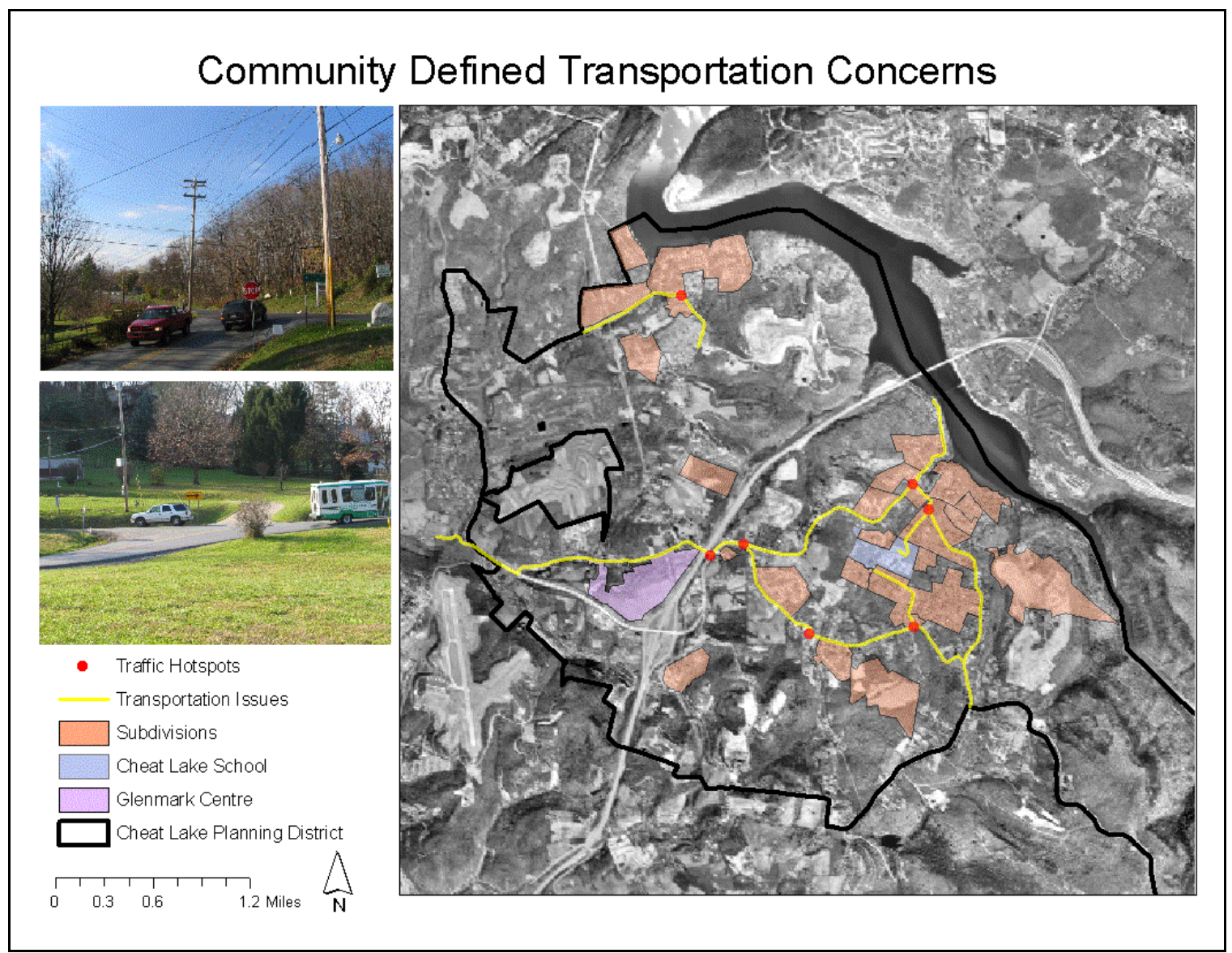

Figure 4.4 Community Defined Transportation Concerns

The intersection of 857 and Tyrone Avery Road (the top left photograph in Figure 4.4 above) was mentioned several times by participants as a traffic hotspot. Key Informant \#1's comments (November 2004) discuss traffic concerns in this area:

There is a need for a stoplight where the Tyrone Avery Church is. If you go there at the wrong time, between seven and nine in the morning you might be in for a lot of trouble. You can't get a good view because of the hill and because of people driving fast around the curves. It's really very interesting in the winter because you are going up the hill [towards 857] and you are just hoping that nothing's coming there because if you stop there at the top, you might not get to work that day.

A second major traffic concern mentioned by participants is located at the intersection of Crosby Road and Tyrone Road, which serves as the entrance to the Cheat Lake Schools. One participant's comments highlight the concerns in this area (Focus Group \#2, December 2004): 
There's not good access to it [the school] and we get lots of traffic in the morning and in the afternoon when the parents are dropping kids off and picking them up. The traffic doesn't bother me...it's the rate that they come in and out. It is a real big frustration to me because I like to walk the dog and I mean we do it but it could be safer. I have a problem with how fast they drive to drop their kids off and how little regard they have for pedestrians. I've driven down at Tyrone where Crosby comes in the morning and the cars are packed-up over Tyrone to get on to Crosby and to get off of Crosby.

\section{Potential Preservation Opportunities}

At the beginning of this project, members of the planning district advisory committee and the county planner stressed that protecting and preserving remaining open and green spaces was an important priority for current and future planning discussions (refer to chapter three). The PGIS process allowed participants to identify and map areas they felt should be protected if zoning regulations were put in place in the future. As one resident notes in a focus group discussion: "the government should require that every time land is purchased for development, 10 to $15 \%$ of that land should be set aside for green space.”

Participants in another focus group (Focus Group \#1, November 2004) point to two large parcels that need protection from future development:

Two areas still have sizable farms and areas for preservation. The one is off the Canyon Road...it is the Old Judy property. The other is the area owned by Greer [site of Greer Industries off of Canyon Road]. If all of a sudden Greer decided to sell and then Judy decided to sell and you have development here, that could be a problem. These two chunks of land should be preserved as green space.

Building upon the comments about preservation mentioned above, Figure 4.5 (below) highlights a composite map of participant-defined potential preservation areas. The advisory committee plans to query this information with land ownership data to determine which owners should be encouraged to attend future preservation discussions. The committee also hopes to use this information to show how few preservation opportunities remain in the planning district and to convince large property owners to protect their land, rather than sell it to developers. Based upon comments made from this study, there has also been discussion about creating incentive programs for land owners to preserve their land, rather than sell it to developers. 


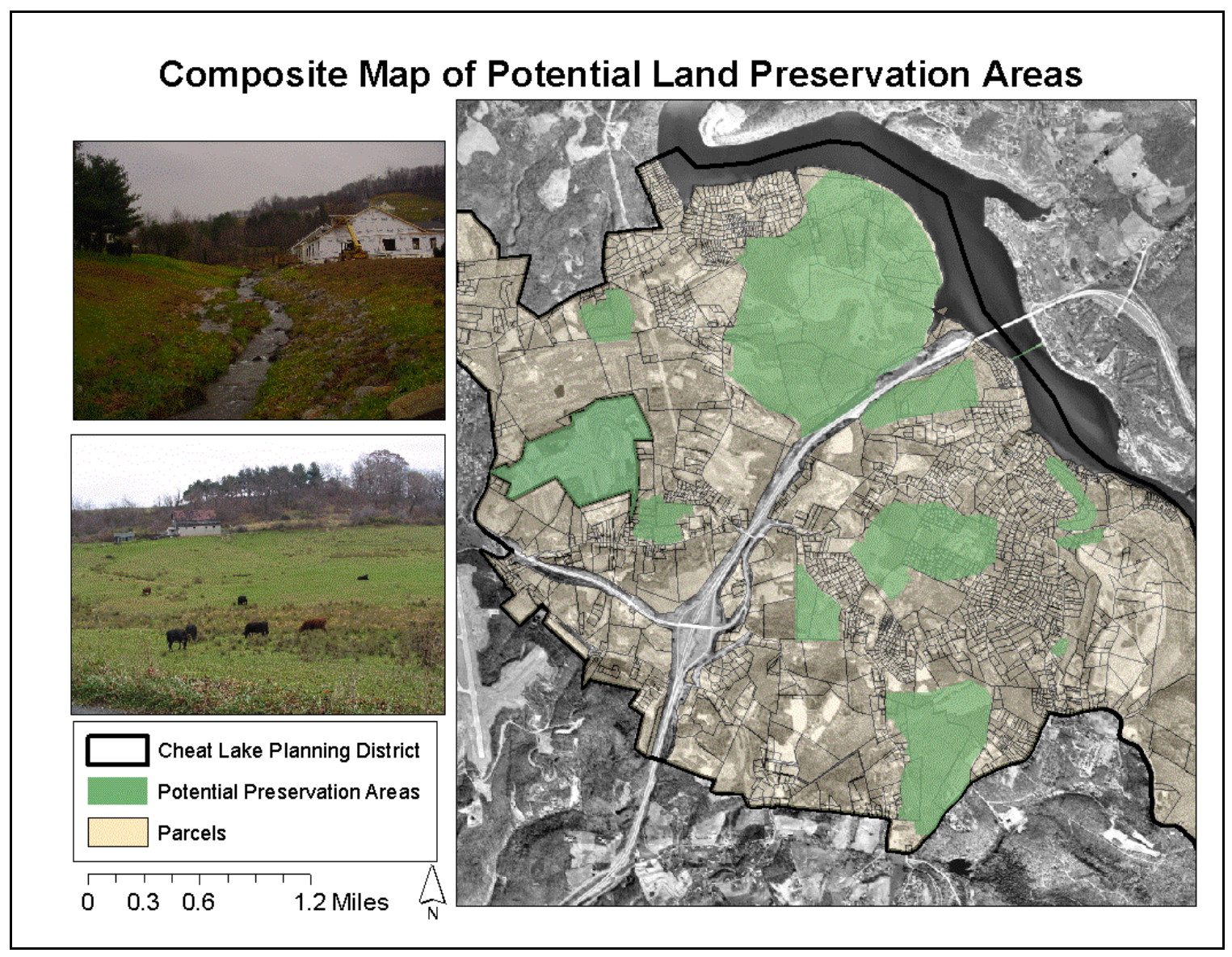

Figure 4.5 Composite Map of Preservation Opportunities

While large areas of land with preservation potential were identified through the PGIS process, other preservation opportunities were also identified. Three focus groups and two key informants stressed the need for recreational trails and walkways in the planning district. Figure 4.6 (below) shows a composite map of potential trails and walkways compiled by community members. Throughout the PGIS process, participants suggested that more recreational opportunities needed to be added in the community, as shown by one resident's comments: “it would be nice to have shoulders and sidewalks and bike paths. I wish there were sidewalks of some sort so I could get out and walk without fighting the traffic. If there were sidewalks and wider shoulders that could help slow down the traffic.” Another participant agreed with these comments stating that: "there are not nearly enough land use opportunities for bringing physical activity into your daily life. It's a shame people have to drive ten miles to exercise.” These comments suggest that participants want preservation areas set aside for recreational opportunities. 
Comments from participants and the PGIS layer of potential trails and walkways will be used by the advisory committee to start a discussion about the possibility of locating trails and walkways in the planning district. It is important to note that information collected from this study serves as the first attempt at collecting public input for potential trail and walkway system locations in the planning district.

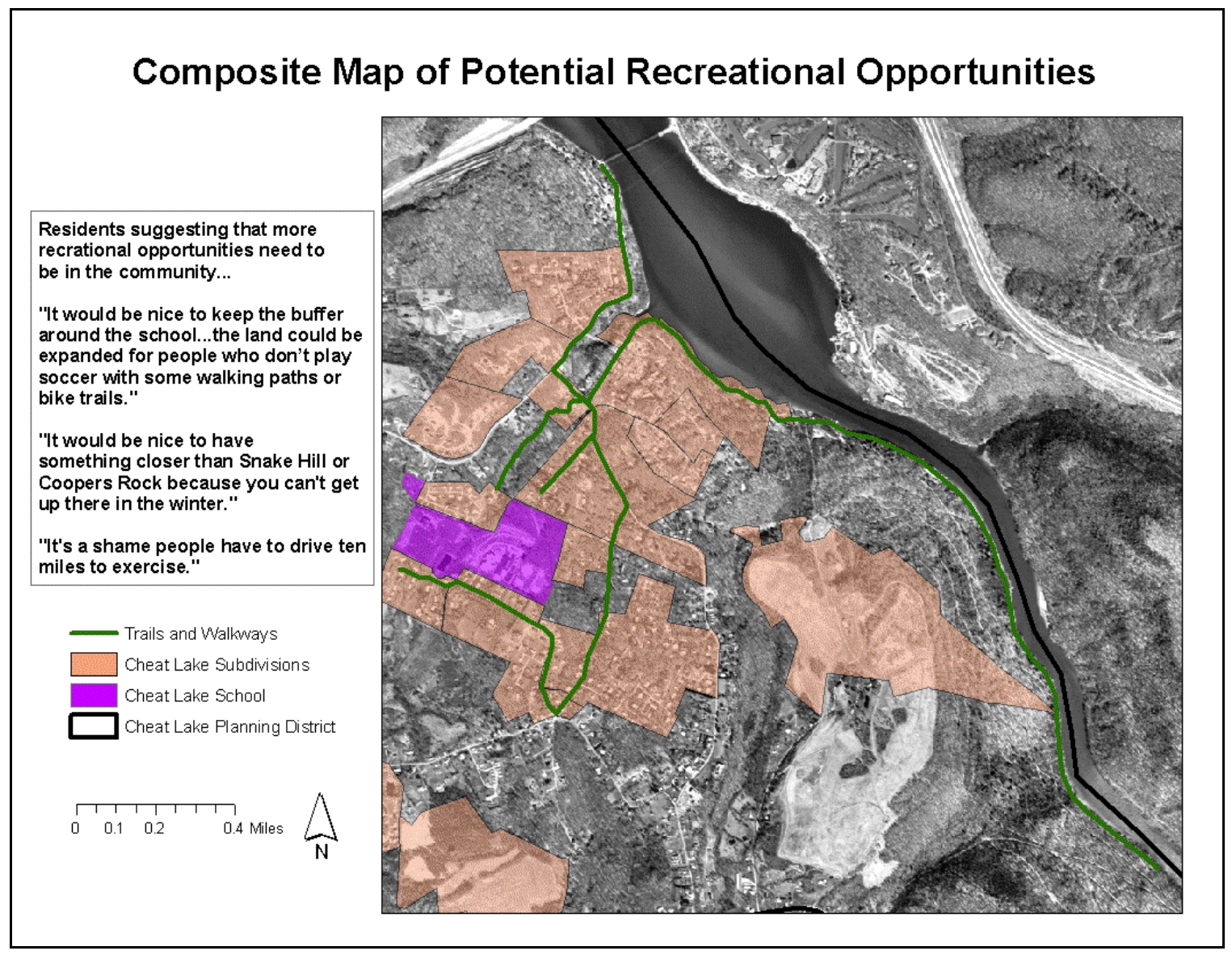

Figure 4.6 Composite Map of Trails and Walkways

In four focus group discussions and two key informant interviews, the old Cheat Lake Bridge was also identified as a major preservation opportunity. As one resident suggests, "I really think that the old bridge is vitally important to this area. Just imagine for us - with all the things we do over the other side of the Cheat - if that old bridge was going down you have to go up [and get on Interstate 68] and that would take all morning.” As Figure 4.7 (below) and the comments above show, residents believe that the bridge serves an integral transportation role in the area. Learning about preserving the old bridge serves as one example of the power of community local knowledge: typical 
geo-spatial data would not have been able to identify the old bridge as an important preservation opportunity.

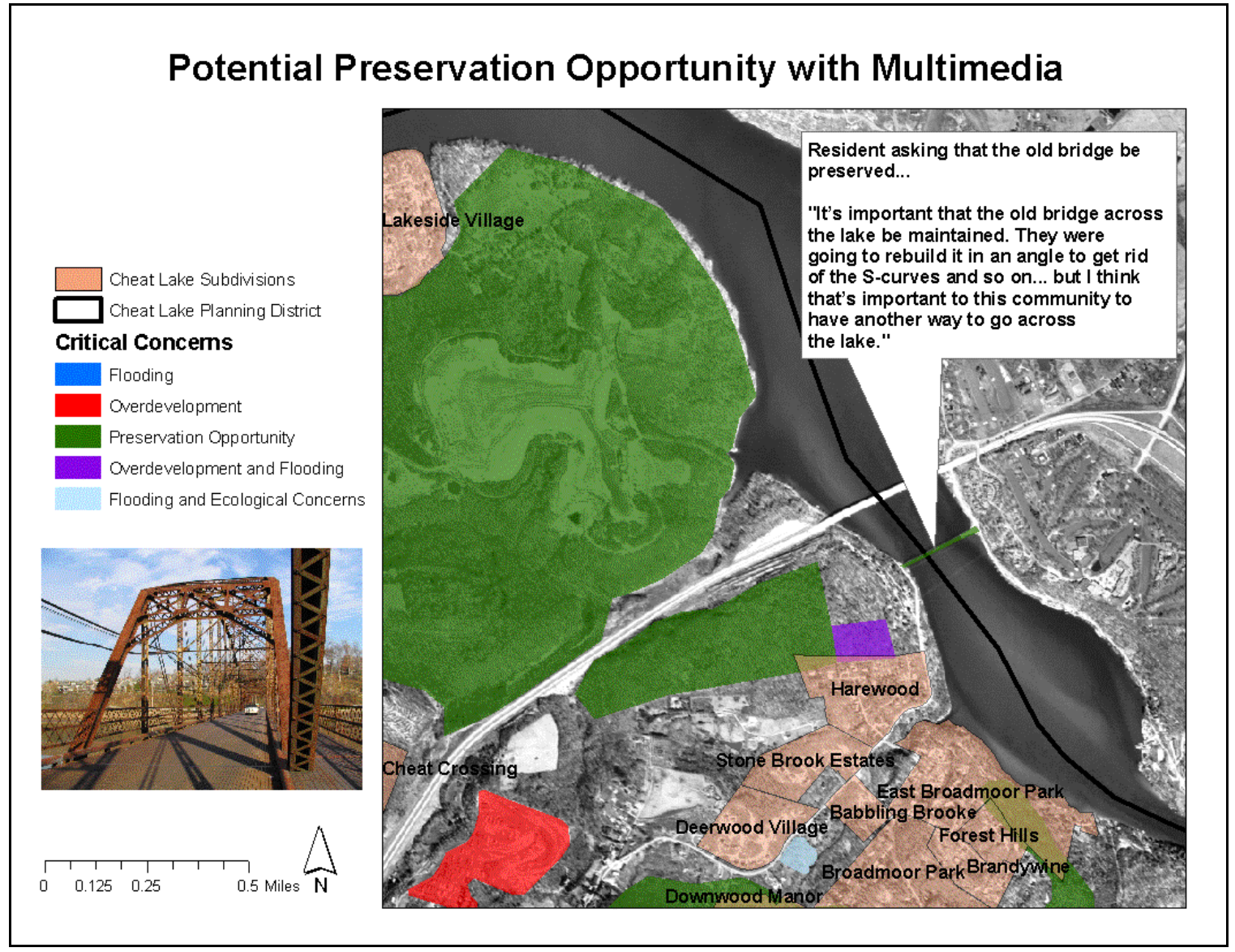

Figure 4.7 Potential Preservation Opportunity

\section{Community-Defined Land Use Themes}

As the above discussion and figures highlight, the collaborative PGIS process yielded some tangible results in the form of a PGIS of community-defined land use themes. While these land use concerns are only representative of the limited amount of groups and individuals who participated in the research process, they do serve as a starting point for future discussions about critical community concerns. In creating a PGIS of community-defined issues, the WVU research team highlights the potential of integrating community local knowledge into land use planning and also collects information that can be used by the CLPDAC for future planning discussions and larger public meetings. 


\subsection{Conclusion}

Findings of the PGIS research are reviewed in this chapter. It is demonstrated how participation is improved through the use of PGIS, how local political context affects PGIS, how PGIS methods can help answer a community's questions, how empowerment occurs through the integration of PGIS methods, and how critical community concerns can be represented with PGIS. From discussions forged in this chapter, it is concluded that a PGIS methodology can also result in tangible products for use in local planning discussions, including GIS layers representing community concerns regarding: overdevelopment and increasing population densities, clear cutting, flooding hotspots, transportation and traffic concerns, potential preservation areas, and potential recreational trails and walkways. 


\section{Chapter 5: Summary and Conclusion}

The main objectives of this thesis research were to link land use planning with geo-spatial technologies through a PGIS methodology and allow the advisory committee to learn more about community land use concerns in ways that would not have been possible in a typical county land use planning process. As discussed in the land use planning literature review (chapter two), public participation in land use planning is often symbolic, rather than substantive. The field-based PGIS methodology implemented in the case study area moves beyond the symbolic nature of participation found in larger public planning meetings. By implementing a field-based Participatory GIS methodology that includes focus group discussions, in-depth key informant interviews, and participatory mapping exercises, participants were able to share their expert knowledge of the study area, discuss and map critical land use concerns, and interact with geo-spatial data in a way that would not have been possible in the traditional top-down public meeting.

In addition to improving participation in local land use planning, this thesis research implemented a low-technology participatory approach borrowed largely from the participatory development and PGIS literatures. As many PGIS and participatory development researchers suggest (refer to the discussion in chapter two), choosing the proper technologies and methods plays an integral role in shaping participation in participatory projects. A low-technology field-based approach worked well in the case study area. As the research team learned at the beginning of the PGIS process, local residents were hesitant to get involved due to the team's desire to include advanced geospatial technologies and extensive land use and cover change information exercises. This thesis research benefited from the team's willingness to adapt to the needs of local residents, the advisory committee, and the county planner.

While the major objective of this thesis research was to create more meaningful opportunities for participation in local land use planning, the research also integrated community local knowledge into PGIS. By holding focus group discussions, key informant interviews, and participatory mapping exercises, the research team collected local knowledge from members of the community, integrated this knowledge into GIS with existing geo-spatial data, and created a database that highlighted land use concerns 
discussed by members of the community. A summary of the critical community themes discussed and mapped by participants includes:

- Overdevelopment and Increasing Population Densities

- Clear Cutting for New Development

- Flooding Hotspots

- Transportation and Traffic Concerns

- Potential Preservation Areas

- Potential Recreational Trails and Walkways

The final product, a PGIS of community local knowledge, can be used by the advisory committee to help gain support for land use planning, to help educate the public about land use concerns, and to help gain momentum for upcoming land use planning and zoning discussions, which judging by past planning failures at the local level could prove to be controversial and open to contentious debate.

As discussed in chapter three of this thesis, both the Participatory GIS and land use planning literatures stress that local knowledge and public participation are important aspects of community planning. Both literatures suggest that more needs to be done to ensure: 1) local participants are given meaningful opportunities for participation, 2) local qualitative information held by participants is given a more prominent role in land use planning discussions, 3) different people and interest groups work together in an attempt to reach consensus about critical community land use issues, and 4) all segments of society are encouraged to actively participate in land use planning.

As this thesis research demonstrates, planners, universities, and local communities can use PGIS methods in a collaborative manner as they attempt to reach the four goals stated above. A PGIS methodology offers a highly effective visual communication, analysis, and representation tool for public participation in land use planning.

While implementing a low-technology field-based PGIS methodology proved useful for encouraging participation, the approach also has important limitations. In choosing not to include more advanced spatial analysis capabilities, such as a dynamic land use and cover change analysis, the team may have missed an opportunity to strengthen the argument for land use planning and zoning regulations in the case study area. A land use and cover change analysis documenting change over the past twenty 
years could have made for a dramatic display highlighting extensive land cover change in the study area.

Participation biases also presented a minor limitation to this thesis research. The collaborative PGIS approach used in this study is biased towards residents who chose to participate or those who felt strongly about zoning and planning issues; therefore, the methodology is limited in that it cannot be characterized as representative of the entire Cheat Lake Planning District population. These biases are similar to biases that occur in typical planning processes where supporters and opponents come out to voice their opinions, while the majority of the population chooses not to attend. While attempts were made to meet with participants and communities that do not typically participate in local land use planning (e.g. lower income residents, zoning opponents, marginalized communities), other groups of people and communities were not interviewed as part of this research project. Despite this limitation, the methodology succeeded as a test methodology showing the viability of integrating local knowledge into PGIS for land use planning.

\section{Future Work}

As evident from participant comments, there is a growing frustration with land use problems in the planning district. Public reaction to these land use issues may be signifying a shift in local attitudes to zoning and planning regulations. As one focus group discussion suggests, residents are thinking about the impact uncontrolled growth is having in their community: "it seems to me that pretty soon we are going to be locked out at some point. It's not going to be the utility and infrastructures... and they [developers] are not going to be able to develop because there's not going to be the infrastructure to support them [development]..." As one member of the advisory committee notes, the county must find a way to help combat the growth and development issues: "you can't knock down the houses that are already built here. You can't do that. They're already going to be there, so you already have the density. That's why you have the infrastructure problems and you have traffic problems. Now how you keep that from growing exponentially, that has to be the regulation role for the future.” 
In conducting this thesis research, it was learned that many participants are eager for land use planning and zoning regulations in the Cheat Lake Planning District. While it is recognized that the participatory process in this thesis attracted more supporters than opponents, it is important to note that the process helped educate members of the public about the need for zoning and planning regulations and also allowed participants to discuss critical issues in their planning district. While all participants may not have supported government-sanctioned zoning regulations, participants were given an opportunity to share their land use concerns. All indications from the county planning office suggest that these comments will be considered by local government officials as they attempt to draft zoning and planning regulations for the case study area. To ensure that this occurs, community members must continue to apply pressure to local officials to ensure that their voices are heard and action is taken.

While this study serves as a solid foundation for future public participation efforts in the Cheat Lake Planning District, it is imperative that the county planning commission and the planning district advisory committee work collaboratively to engage more members of the public into local planning. There are several indications that collaborative planning practices will indeed continue within the district. As the county planner discussed at the July 2005 county planning commission meeting, the planning office will use the citizen comments and PGIS community-defined layers in a variety of ways.

First, the information compiled from this study, including PGIS layers will be integrated into the county planning office website where community members will be able to view the data to learn more about land use issues, residents will also be able to email comments about the information to the county planning director for further discussion, and residents will be able to find out when future public participation opportunities will occur. The county planner has also inquired into the possibility of adding an ArcIMS to the website with a suite of basis PGIS tools, such as pan/zoom options, overlay functionality, multimedia, text writing tools, and discussion boards.

Second, the information compiled from this thesis will be used by the county planning office as they embark on a continued public participation effort with a private consulting agency in the coming months. The agency will use the information collected 
from this thesis as the basis for formulating group exercises designed to learn more about community land use concerns and future visions for the planning district.

Third, this work will be used as the basis for an innovative public participation experience in the Cheat Lake Middle School. According to the county planner, in late 2005, members of the planning office will conduct a simplified version of this project with sixth and seventh graders to learn about their visions for the community. It is hoped that the middle school study will encourage children to have a voice in shaping the future of the community and also raise awareness from discussions between children and their parents.

The final outcome of this thesis research, along with future public participation efforts, is to create preliminary zoning maps for the district, which can then be discussed during several public planning meetings. As shown above, it appears likely that this research has improved public participation efforts in the planning district and will have many positive effects in the future. It is pivotal that members of the WVU research team continue to work in conjunction with the planning district advisory committee and the county planning commission to expand upon the findings of this research and to ensure that more participants and communities are included in the Cheat Lake collaborative planning process.

\section{Conclusion}

This thesis research uses a PGIS methodology to link land use planning with geospatial technologies in order to help the Cheat Lake Planning District advisory committee

gather public opinion about land use issues. The benefits of increased participation include:

- Increased public education and awareness about land use planning

- Inclusion of participant defined issues in PGIS

- Addition of information that may not have been easy to recognize with typical geo-spatial data

- Increased support for land use planning and zoning regulations in the community. 
Implementing a field-based PGIS methodology helps integrate community local knowledge and creates opportunities for participation in land use planning in a way that moves beyond the symbolic nature of participation found in the traditional public meeting. 


\section{Literature Cited}

Abbot, J., R. Chambers, C. Dunn, T. M. Harris, E. de Merode, G. Porter, J. Townsend, and D. Weiner. (1998). Participatory GIS: Opportunity or oxymoron. PLA Notes, 33, 27-34.

Alagan R. (2003). Participatory geographic information systems into environmental impact assessment: Case study of the Corridor $\mathrm{H}$ transportation development project, retrieved from the WWW on February 12, 2004 at http://www.geo.wvu.edu/ ralagan/PGIS_EIA/pgis_page.htm

Aitken, S. C. (2002). Public Participation, technological discourses and the scale of GIS. In Craig, W., Harris, T.M., and Weiner, D. (Ed.). Community Participation and Geographic Information Systems. (pp. 357-366). London: Taylor and Francis.

Aitken, S. C. and Michel, S. (1995). Who contrives the "real” in GIS? Geographic information, planning and critical theory. Cartography and Geographic Information Systems, 22(1), 17-29.

Al-Kodmany, K. (2002). Visualization tools and methods in community planning: from freehand sketches to virtual reality. Journal of Planning Literature, 17(2), 189211.

Al-Kodmany, K. (2001). "Bridging the gap between technical and local knowledge: tools for promoting community-based planning and design.” Journal of Architectural and Planning Research, 18(2), 110-130.

Al-Kodmany, K. (2000). Extending geographic information systems to meet neighborhood planning needs: The case of three Chicago communities. URISA Journal, 12(3), 19-37.

Arksey, H. and Knight, P. (1999). Interviewing for Social Scientists. London: Sage Publications.

Barndt, M. (2002) A model for evaluating public participation GIS, In Craig, W., Harris, T.M., and Weiner, D. (Ed.), Community participation and geographic information systems (pp. 346-356). London: Taylor and Francis.

Baxter, J. and Eyles, J. (1997). Evaluating qualitative research in social geography: establishing 'rigour' in interview analysis. Transactions of the Institute of British Geographers 22, 505-525.

Bedford, T. and Burgess, J. (2001). The focus-group experience. In Limb, M. and Dwyer, C. (Ed.). Qualitative Methodologies for Geographers: Issues and Debates (pp. 121-135). London: Arnold Publishing.

Bradshaw, M. and Stratford, E. (2000). Qualitative research design and rigour. In Hay, I. (Ed.). Qualitative Research Methods in Human Geography. (pp. 37-49). Victoria, Australia: Oxford University Press.

Brisbin, R., and Hunter, S. (2004). Planning for the future: An introduction to land use policy options for West Virginia. The West Virginia Public Affairs Reporter, 21(1), 2-9.

Brody, S., Godschalk, D., and Burby, R. (2003). Mandating citizen participation in plan making: Six strategic planning choices. Journal of the American Planning Association, 69(3), 245-263. 
Burby, R. (2003). Making plans that matter: Citizen involvement and government action. Journal of the American Planning Association, 69(1), 33-49.

Cameroon, J. (2000). Focusing on the focus group, In Hay, I. (Ed.). Qualitative Research Methods in Human Geography. (pp. 83-102). Victoria, Australia: Oxford University Press.

Carvell, K. (2004). Oral history of the Cheat Lake area, West Virginia.

Carver, S., Evans, A., Kingston, R., and Turton, I. (2000). Accessing geographical information systems over the World Wide Web: Improving public participation in environmental decision-making. Information Infrastructure and Policy, 6, 157170.

Casey, L. and Pederson, T. (2002) Mapping Philadelphia’s neighbourhoods, In Craig, W., Harris, T.M., and Weiner, D. (Ed.). Community participation and geographic information systems (pp. 65-77). London: Taylor and Francis.

Cheat Lake Planning District Advisory Committee. (2004). July 2004 CLPDAC public meeting, Cheat Lake, West Virginia Library.

Chrisman, N. R. (1987). Design of geographic information systems based on social and cultural goals. Photogrammetric Engineering and Remote Sensing, 53(10), 13671370.

Clark, G. L. (1991). GIS - what crisis? Environment and Planning A 23(12), 321-322.

Coulson, A. (2003). Land-use planning and community influence: A study of Selly Oak, Birgmingham. Planning, Practice, and Research, 18(2-3), 179-195.

Craig, W. and Elwood, S. (1998). How and why community groups use maps and geographic information. Cartography and Geographic Information Systems, 25(2), 95-104.

Craig, W. J., Harris, T. M., and Weiner, D. (2002). Community participation and geographic information systems. London: Taylor and Francis.

Crampton, J. (1995). The ethics of GIS. Cartography and Geographic Information Systems, 22(1), 84-89.

Crewe, K. (2001). The quality of participatory design: The effects of citizen input on the design of the Boston southwest corridor. Journal of the American Planning Association, 67(4), 437-455.

Curry, M.R. (1995). Rethinking rights and responsibilities in geographic information systems: Beyond the power of the image. Cartography and Geographic Information Systems, 22(1), 58-69.

Day, D. (1997). Citizen participation in the planning process: An essentially contested concept? Journal of Planning Literature, 11(3), 421-434.

Dobson, J. E. (1993). Open Forum: The geographic revolution: A retrospective on the age of automated geography. Professional Geographer, 45(4), 431-439.

Docherty I., Goodland, R., and Paddison, R. (2001). Civic culture, community and citizen participation in contrasting neighborhoods. Urban Studies, 48(12), 2225-2250.

Dueker, K. J. (1987). Multipurpose land information systems: Technical, economic, and institutional issues. Photogrammetric Engineering and Remote Sensing, 53(10), 1361-1365.

Dunn, K. (2000) Interviewing in Hay I. (ed.) Qualitative Research Methods in Human Geography. Victoria, Australia: Oxford University Press. (pp. 50-82). 
Edney, M. H. (1991). Strategies for maintaining the democratic nature of geographic information systems. Papers and Proceedings of the Applied Geography Conferences.

Elwood, S. (2002). The impacts of GIS use in Minneapolis. In Craig, W., Harris, T.M., Weiner, D. (Ed.), Community participation and geographic information systems (pp. 77-88). London: Taylor and Francis.

Fischler, R. (2000). Case studies of planners at work. Journal of Planning Literature, 15(2), 184-195.

Fleick. R. and Hall, G. (1999). Consensus-building in a multi-participant spatial decision support system. URISA Journal, 11(2), 17-23.

Fletcher, C. (2005). Land use planning in Monongalia County, West Virginia.

Ghose, R. and Huxhold, W. (2001). The role of local contextual factors in building public participation GIS: The Milwaukee experience. Cartography and Geographic Information Science, 28(3), 195-208.

Goodchild, M. (1995). Geographic information systems and geographic research. In Pickles, J. (Ed.) Ground Truth: the social implications of GIS. (pp. 31-50). New York: Guildford Press.

Goodchild, M. (1991). Comment: Just the facts. Political Geography Quarterly, 10(4), 335-337.

Goss, J. (1995). We know who you are and we know where you live: The instrumental rationality of geodemographic information systems. Economic Geography, 71, 171-198.

Hanna, K. (2000). The paradox of participation and the hidden role of information: A case study. Journal of the American Planning Association, 66(4), 398-410.

Harris, T.M. and Weiner, D.(2003). Linking community participation to geospatial technologies. Aridlands Newsletter, 53.

Harris, T.M. and Weiner, D. (2002). Implementing a community-integrated GIS: perspectives from South African Fieldwork, In Craig, W. J., Harris, T. M., and Weiner, D. (Ed). Community participation and geographic information systems. (pp. 246-258). London: Taylor and Francis.

Harris, T. and Weiner, D. (1998). Empowerment, marginalization and communityintegrated GIS. Cartography and Geographic Information Systems, 25(2), 67-76.

Harris, T. M., Weiner, D., Warner, T., and Levin, R. (1995). Pursuing social goals through participatory GIS: Redressing South Africa's historical political ecology. In J. Pickles (Ed.) Ground truth: The social implications of geographic information systems (pp. 196-222). New York: Guilford Press.

Hawthorne, T.L., Elmes, G., Fletcher, C., McCusker, B., Pinto, M., and Weiner, D. (forthcoming). Beyond the public meeting: Building a field-based participatory geographic information system for land use planning in Monongalia County, West Virginia, In Collaborative geographic information systems.

Innes, J. (1998). Information in communicative planning. Journal of the American Planning Association, 64(1), 52-63.

Innes, J. and Booher, D. (1999a). Consensus building as role playing and bricolage. Journal of the American Planning Association, 65(1), 9-26. 
Innes, J. and Booher, D., (1999b). Consensus building and complex adaptive systems: A framework for evaluating collaborative planning. Journal of the American Planning Association, 65(4), 412-423.

Krygier, J. B. (2002). A praxis of public participation GIS and visualization. In Craig, W., Harris, T.M., and Weiner, D. (Ed.). Community Participation and Geographic Information Systems. (pp. 340-355). London: Taylor and Francis.

Kwaku-Kyem, P. (2002). Promoting local community participation in forestry management through a ppgis application in southern Ghana. In Craig, W., Harris, T. M., and Weiner, D. (Ed.), Community participation and geographic information systems (pp. 218-231). London: Taylor and Francis.

Lake, R.W. (1993). Planning and applied geography: Positivism, ethics, and geographic information systems. Progress in Human Geography, 17(3), 404-413

Laurian, L. (2004). Public participation in environmental decision making. Journal of the American Planning Association, 70(1), 53-66.

Laurian, L. (2003). A prerequisite for participation: Environmental knowledge and what residents know about local toxic sites. Journal of Planning Education and Research, 22, 257-269.

Leitner, H., McMaster, R. B., Elwood, S., McMaster, S., and Sheppard, E. (2002). Models for making GIS available to community organizations: Dimensions of difference and appropriateness. In Craig W., Harris, T.M., and Weiner, D (Ed.) Community participation and geographic information systems (pp. 37-52). London: Taylor and Francis.

Leitner, H., Elwood, S., Sheppard, E., McMaster, S., and McMaster, R. (2000). Models of provision and their appropriateness for neighborhood organizations: Examples from Minneapolis and St. Paul, Minnesota. URISA, 12(4), 43-56.

Mackay, E. (1982). The role of information in the economic world view. In Economics of Information and Law. Boston: Kluwer Nijhoff.

Margerum, R. (2002). Evaluating collaborative planning: Implications from an empirical analysis of growth management. Journal of the American Planning Association, 68(2), 179-193.

Obermeyer, N. J., 1998, HUD's community connection for local empowerment. Paper presented at NCGIA Special Meeting: Empowerment, Marginalization and Public Participation GIS, Santa Barbara, CA, Retrieved from the WWW on March 15, 2005 at http://www.nciga.ucsb.edu/varenius/ppgis/papers/index.htm

Obermeyer, N. J. (1995). The hidden GIS technocracy. Cartography and Geographic Information Systems, 22(1), 78-83.

Openshaw, S. (1998). GIS and Society: a lot of fuss about very little that matters and not enough about that which does! NCGIA Initiative 19 Position Paper, Retrieved from the WWW on March 2, 2005 at http://www.geo.wvu.edu/i19/papers/openshaw.html

Peng, Z. (2001). Internet GIS for public participation. Environment and Planning B: Planning and Design, 28(6), 889-905.

Pickles, J. (1999). Arguments, debates, and dialogues: The GIS-social theory debate and concerns for alternatives. In M. G. Longley P., D. Maguire, D. Rhind (Ed.), Geographical information systems: Principles, techniques, management, and applications. New York: John Wiley. 
Pickles, J. (1995). Ground truth: The social implications of GIS. New York: Guilford Press.

Sheppard, E. (1993). GIS and society: Ideal and reality, Friday Harbor Conference. Friday Harbor, Washington.

Seidman, I. (1998). Interviewing as Qualitative Research. New York: Teachers College Press.

Talen, E. (2000). Bottom-up GIS: A new tool for individual and group expression in participatory planning. APA Journal, 66(3), 279-294.

Taylor, P.J. (1991). A distorted world of knowledge. Journal of Geography in Higher Education, 15, 85-90.

Taylor, P.J. (1990). GKS. Political Geography Quarterly, 3, 211-212.

Taylor, P.J. and Overton, M. (1991). Further thoughts on geography and GIS. Environment and Planning A, 23, 1087-1094.

URISA. (2002, July 21-23). Conference proceedings of the "1st annual ppgis conference" sponsored by urban and regional information systems association. Rutgers University School of Planning and Public Safety, New Brunswick, NJ.

URISA. (2003, July 20-22). Conference proceedings of the " $2^{\text {nd }}$ annual ppgis conference" sponsored by the urban and regional information association. Portland State University, Portland, Oregon.

URISA. (2004, July 18-20). Conference proceedings of the "3rd annual ppgis conference" sponsored by urban and regional information systems association. University of Wisconsin-Madison, Madison, WI.

Ventura, S., Niemann, B., Sutphin, T., and Chenoweth, R. (2004). GIS-enhanced land use planning in Dane County, Wisconsin, Retrieved from the WWW on February 22, 2004 at http:www.ncgia.ucsb.edu/varenius/ppgis/papers/ventura.html

Ward-Schofield, J. (1993). Increasing the generalisability of qualitative research. In M. Hammersly (ed.) Social Research: philosophy, politics and practic. Open University Press (pp. 200-225).

Weiner, D., Warner, T.A., Harris, T.M., and Levin, R.M. (1995). Apartheid representations in a digital landscape: GIS, remote sensing and local knowledge in Kiepersol, South Africa. Cartography and Geographic Information Systems, 22(1), 30-44.

Winchester, H. (2000). Qualitative research and its place in human geography. In I. Hay (ed.) Qualitative Research Methods in Human Geography. Victoria, Australia: Oxford University Press (pp. 1-22).

Zaferatos, N. (2004). Tribal nations, local governments, and regional pluralism in Washington state: The Swinomish approach in the Skagit Valley. Journal of the American Planning Association, 70(1), 81-96.

Zubrow, A. (2003). Mapping tension: Remote sensing and the production of a statewide land cover map. Human Ecology, 31(2), 281-307. 